\title{
Role of Mesenchymal Stem Cells in Bone Regenerative Medicine: What Is the Evidence?
}

\author{
Ahmad Oryan $^{\mathrm{a}}$ Amir Kamali $^{\mathrm{a}} \quad$ Ali Moshiri $^{\mathrm{b}} \quad$ Mohamadreza Baghaban Eslaminejad ${ }^{\mathrm{c}}$

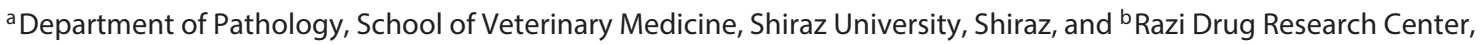 \\ Iran University of Medical Sciences, and ${ }^{\mathrm{C}}$ Department of Stem Cells and Developmental Biology, Cell Science Research \\ Center, Royan Institute for Stem Cell Biology and Technology, ACECR, Tehran, Iran
}

\section{Keywords}

Mesenchymal stem cells - Bone regeneration - Bone tissue engineering

\begin{abstract}
Healing and regeneration of bone injuries, particularly those that are associated with large bone defects, are a complicated process. There is growing interest in the application of osteoinductive and osteogenic growth factors and mesenchymal stem cells (MSCs) in order to significantly improve bone repair and regeneration. MSCs are multipotent stromal stem cells that can be harvested from many different sources and differentiated into a variety of cell types, such as preosteogenic chondroblasts and osteoblasts. The effectiveness of MSC therapy is dependent on several factors, including the differentiating state of the MSCs at the time of application, the method of their delivery, the concentration of MSCs per injection, the vehicle used, and the nature and extent of injury, for example. Tissue engineering and regenerative medicine, together with genetic engineering and gene therapy, are advanced options that may have the potential
\end{abstract}

\section{KARGER}

(C) 2017 S. Karger AG, Basel

E-Mail karger@karger.com

www.karger.com/cto to improve the outcome of cell therapy. Although several in vitro and in vivo investigations have suggested the potential roles of MSCs in bone repair and regeneration, the mechanism of MSC therapy in bone repair has not been fully elucidated, the efficacy of MSC therapy has not been strongly proven in clinical trials, and several controversies exist, making it difficult to draw conclusions from the results. In this review, we update the recent advances in the mechanisms of MSC action and the delivery approaches in bone regenerative medicine. We will also review the most recent clinical trials to find out how MSCs may be beneficial for treating bone defects.

(c) 2017 S. Karger AG, Basel

\section{Introduction}

Bone has a self-repair ability so that it can repair itself when the nature and extent of injury is not large, chronic, severe, and complicated. Bone healing is a complex process of overlapping phases, including inflammation, repair, and remodeling that involves the many intracellular

Prof. Ahmad Oryan, DVM, PhD

Department of Pathology, School of Veterinary Medicine, Shiraz University PO Box 71345-1731

Shiraz (Iran)

E-Mail oryan@ shirazu.ac.ir 


\begin{tabular}{ll}
\hline Abbreviations used in this paper \\
\hline ADMSCs & adipose tissue-derived mesenchymal stem cells \\
BMAC & bone marrow aspirate concentrate \\
BMPs & bone morphogenetic proteins \\
bMSCs & bone marrow stromal cells \\
CSDs & critical-sized bone defects \\
DPSCs & dental pulp stem cells \\
ECD & effective cell dose \\
ECM & extracellular matrix \\
GAM & gene-activated matrix \\
HIF-1 $\alpha$ & hypoxia-inducible factor 1- $\alpha$ \\
IA & intra-arterial \\
IV & intravenous \\
MSCs & mesenchymal stem cells \\
OI & osteogenesis imperfecta \\
PRF & platelet-rich fibrin \\
PRP & platelet-rich plasma \\
SDF1 & stromal-derived factor 1 \\
SVF & stromal vascular fraction \\
TCP & tricalcium phosphate \\
TERM & tissue engineering and regenerative medicine \\
TLRs & toll-like receptors \\
TNF- $\alpha$ & tumor necrosis factor- $\alpha$ \\
VEGF & vascular endothelial growth factor \\
\hline &
\end{tabular}

signaling pathways which are responsible for regeneration of the new bone with the help of surrounding tissues [Oryan and Moshiri, 2013; Oryan et al., 2014b; Moshiri et al., 2015b]. Bone healing is not always completely satisfactory, and many reasons might be responsible for its failure. These include those injuries that cause large bone defects to occur and develop, such as necrosis, tumors (e.g., osteosarcoma), high-energy traumas, and compound-, multiple-, gunshot-, open-, comminuted-, and osteoporosis-related fractures [Frohlich et al., 2008; Amini et al., 2012; Oryan et al., 2015]. This failed healing process can eventually lead to the formation of malunions, delayed unions, nonunions, and osteomyelitis. Today, the correction of bone regeneration impairment has been achieved by advances in healing process management. Using the latest equipment and surgical techniques, better protocols and more effective rehabilitation procedures have contributed to a better prognosis for bone healing [Houlden et al., 2007; Moshiri et al., 2015b]. Despite these advancements, malunions, delayed unions, or nonunions occur and persist in clinical cases where the osteogenesis and subsequent bone remodeling are impaired, particularly in those involving large bone defects [Oryan et al., 2014b].

In order to improve and accelerate the healing process, several options are currently available in clinical practice
[Amini et al., 2012]. First of all, after the diseased bony tissue has been removed and the remaining bones fixed, the resulting defect should be reconstructed and filled with various grafts and materials [Amini et al., 2012; Oryan et al., 2014b; Moshiri et al., 2015b]. An ideal bone graft substitute should have certain properties, including osteoconduction, osteoinduction, osteoincorporation, osteointegration, and osteogenesis [Oryan et al., 2014a]. Despite several efforts that have been made to invent and characterize various bone graft substitutes and engineered tissue scaffolds, none could be globally accepted as an ideal alternative option to autografts due to the low ability of the bone substitutes to enhance osteoinduction and osteogenesis [Zomorodian and Eslaminejad, 2012; Mallick and Cox, 2013; Bigham-Sadegh and Oryan, 2015].

Stem cell therapy, as one of the methods used in the bone repair process, has been developed over the last 2 decades [Giuliani et al., 2013]. The involvement of mesenchymal stem cells (MSCs) in the bone healing process is critical, in particular for difficult nonunion fractures resulting from trauma, blood insufficiency, and other conditions [Grayson et al., 2015; Melek, 2015]. The reparative process of bone regeneration is initiated by MSCs with the formation of soft and hard calluses. Bone remodeling can eventually start after the gap has been filled by this process. Modern strategies of tissue engineering and regenerative medicine (TERM) utilize tissue scaffolds, healing promotive factors (e.g., growth factors such as BMP-2), and MSCs to improve bone repair and regeneration. Most in vitro and many in vivo studies have suggested that the MSCs have the potential to increase osteoinduction and osteogenesis [Li et al., 2007; Otsuru et al., 2007; Hayashi et al., 2008; Pitchford et al., 2009; de Girolamo et al., 2013]. However, little proof is available from the standard clinical trials. In addition, some controversies are apparent between the results and conclusions of the studies, making them difficult to interpret. In order to achieve successful results, an understanding of several mechanisms related to MSCs, such as homing, differentiation, apoptosis, and inflammation, together with various current and future options for which MSCs may be used, is necessary to determine the outcome of cell therapy [Qin et al., 2014b].

In this review we summarize recent advances in understanding of the mechanisms of MSCs in bone repair. Moreover, we update the most important delivery approaches of MSCs in bone TERM. We also review the reported effects of MSC therapy on bone healing in various clinical trials according to the site of damage. The side
60

Cells Tissues Organs 2017;204:59-83

DOI: $10.1159 / 000469704$
Oryan/Kamali/Moshiri/Baghaban Eslaminejad 
Table 1. Advantages and disadvantages of different types of MSCs

\begin{tabular}{|c|c|c|}
\hline Stem cell type & Disadvantages & Advantages \\
\hline $\begin{array}{l}\text { Bone marrow-derived } \\
\text { MSCs }\end{array}$ & $\begin{array}{l}\text { 1. painful acquisition process } \\
\text { 2. lowest proliferative capacity } \\
\text { 3. risk of infection in bone tissue } \\
\text { 4. risk of contamination with malignant cells } \\
\text { when harvested from a patient with a different } \\
\text { malignancy }\end{array}$ & $\begin{array}{l}\text { 1. high stability in culture } \\
\text { 2. accessible source for cell harvesting } \\
\text { 3. high affinity to differentiate into osteoblastic } \\
\text { lineage } \\
\text { 4. ease of preparation }\end{array}$ \\
\hline $\begin{array}{l}\text { Adipose tissue-derived } \\
\text { MSCs }\end{array}$ & $\begin{array}{l}\text { 1. cannot be extracted from cases of severe serous } \\
\text { fat atrophy } \\
\text { 2. high tendency to differentiate into adipocytes } \\
\text { spontaneously } \\
\text { 3. the harvesting and preparation procedure is } \\
\text { longer than with bone marrow MSCs }\end{array}$ & $\begin{array}{l}\text { 1. } 1,000 \text { times more stem cells in } 1 \mathrm{~g} \text { of fat than in } 1 \mathrm{~g} \\
\text { of bone marrow } \\
\text { 2. the pain is much less than with bone marrow } \\
\text { extraction } \\
\text { 3. low risk of infection } \\
\text { 4. easy extraction (e.g., liposuction) } \\
\text { 5. higher cell viability }\end{array}$ \\
\hline $\begin{array}{l}\text { Umbilical cord-derived } \\
\text { MSCs }\end{array}$ & $\begin{array}{l}\text { 1. the access to these MSCs is far less than for } \\
\text { the others } \\
\text { 2. genomic or chromosomal tests need to be } \\
\text { performed in order to examine the healthy } \\
\text { genome }\end{array}$ & $\begin{array}{l}\text { 1. Umbilical cord MSCs exist in the lungs faster than } \\
\text { bone marrow MSCs after IV injection because of a } \\
\text { different expression of adhesion molecules and } \\
\text { glycolipid carbohydrate epitopes } \\
\text { 2. painless collection procedure } \\
\text { 3. faster self-renewal than bone marrow MSCs } \\
\text { 4. have the unique ability to differentiate into } 3 \text { germ } \\
\text { layers }\end{array}$ \\
\hline Peripheral blood MSCs & $\begin{array}{l}\text { 1. low evidence confirming its efficacy } \\
\text { 2. low number that can be harvested from blood }\end{array}$ & $\begin{array}{l}\text { 1. MSCs can be easily and safely obtained from blood } \\
\text { 2. simultaneous extraction of plasma-rich protein. }\end{array}$ \\
\hline
\end{tabular}

effects of this therapy are also illustrated to help readers to draw better conclusions regarding its use. Finally, we discuss the role of TERM approaches in bone healing and illustrate the prospects and directions for the future of MSC-related research.

\section{Mechanisms of MSC Action in Bone Healing}

\section{Characteristics of MSCs}

MSCs are multipotent stromal cells present in most adult connective tissues. They have been extensively studied because of their ability to differentiate into multiple cell types [Eslaminejad and Nadri, 2009; Eslaminejad et al., 2009]. Friedenstein et al. [1970] demonstrated a rare population of plastic-adherent cells in bone marrow (approx. 1 in 10,000 nucleated cells) that were able to form a spindle-shaped cell morphology and round-shaped colonies. These cell clones expanded into round-shaped fibroblastoid colonies, which are termed colony-forming unit-fibroblasts, or CFU-Fs. Some of the colonies could differentiate into bone, cartilage, or adipose tissue [Bianco et al., 2008]. Other research groups extended these

Role of MSCs in Bone Regenerative Medicine initial observations through the study of the proliferative abilities and phenotypic characteristics of CFU-Fs [Caplan and Bruder, 2001; Eslaminejad and Taghiyar, 2010; Eslaminejad et al., 2011; Lotfy et al., 2014; Baker et al., 2015]. MSCs have been widely used in stem cell transplantation, tissue engineering, gene therapy, and immunotherapy [Reiser et al., 2005; Marion and Mao, 2006; Zhao et al., 2016]. These cells express CD105, CD73, and CD90, and are not able to express CD45, CD34, CD14, or CD11b, CD79 $\alpha$ or CD19 antigens. In addition, they are able to differentiate into at least 3 cell lineages in vitro, including chondroblasts, osteoblasts, and adipocytes [Eslaminejad et al., 2007; Wyse et al., 2014]. MSCs can migrate to defect sites and facilitate bone regeneration, but the fundamental mechanisms in this process remain unclear. In regenerative medicine, among all types of stem cells, MSCs are the most commonly used stem cells because of their beneficial properties [Murphy et al., 2013]. The advantages and disadvantages of different types of MSCs are listed in Table 1. MSC populations and maintenance of their homeostasis are established in MSC niches [Ehninger and Trumpp, 2011]. Niches are specific anatomic locations that regulate tissue generation, main-

Cells Tissues Organs 2017;204:59-83

DOI: $10.1159 / 000469704$ 
Fig. 1. Sources of MSCs.

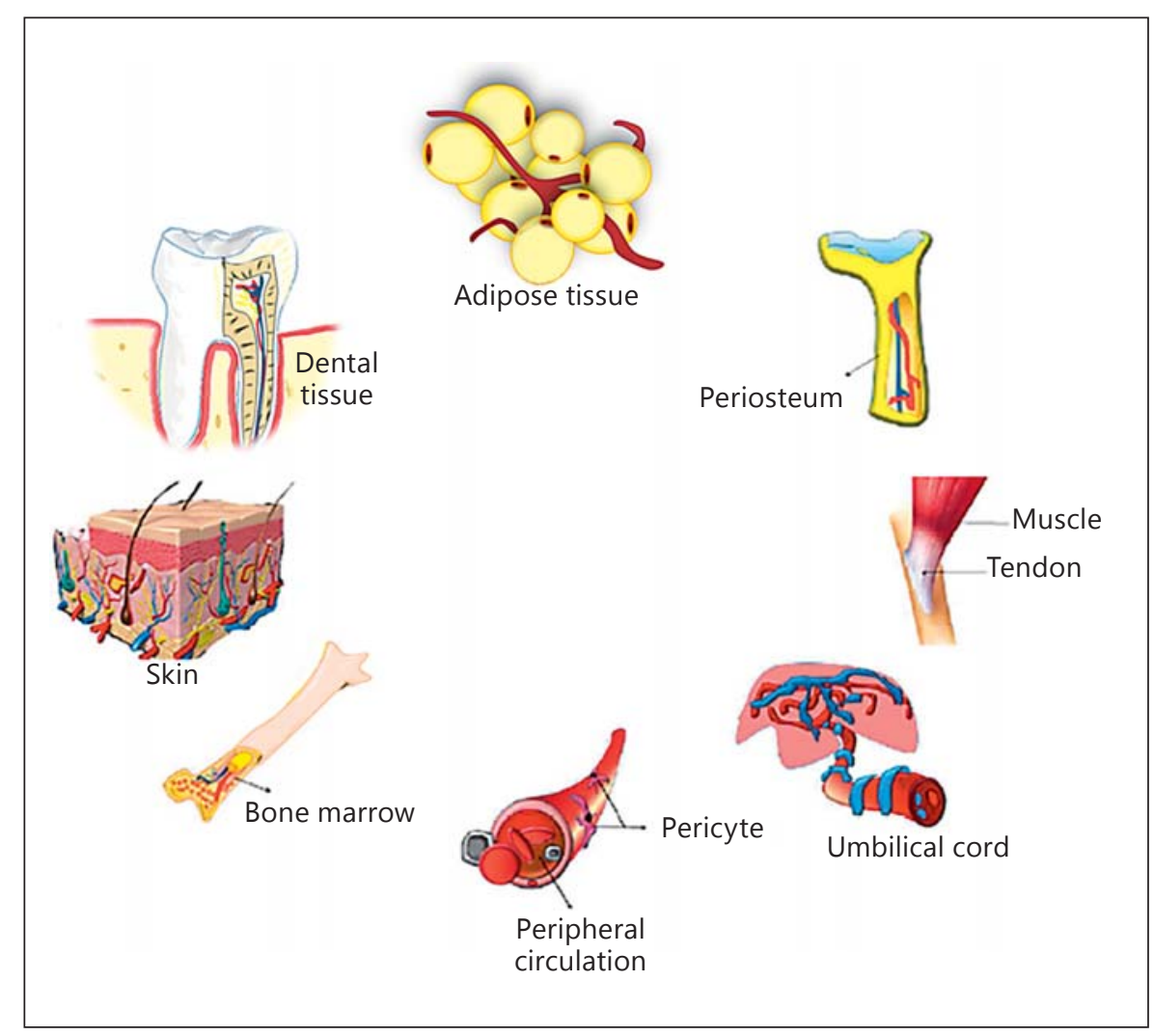

tenance, and repair by MSCs [Glenn and Whartenby, 2014]. The niche has a dual role by which it saves MSCs from depletion and also protects the host from overexuberant MSC proliferation. In fact, it controls the balanced response of MSCs to the necessary requirements of the body [Glenn and Whartenby, 2014]. It may also preclude aberrant function on MSCs or other targets that cause malfunctions. MSC niches are located adjacent to vessel walls, on the endosteal surfaces of trabecular bone, umbilical cord blood (vein, arteries, Wharton jelly, and lining membrane) [Lee et al., 2004], dental tissues (dental pulp, exfoliated deciduous teeth, periodontal ligament, apical papilla, dental follicle, and periapical cyst-MSCs [Kim et al., 2011; Marrelli et al., 2015b], adipose tissue [Zuk et al., 2002], and synovium (synovial membrane and fluid) [Jones et al., 2004]. The sources of MSCs are shown in Figure 1.

\section{MSCs and Immunomodulatory Effects}

Blood clotting and inflammatory reactions are 2 immediate responses when bone fractures occur. In fact, inflammation can initiate the cascades and pathways for bone regeneration by producing chemotactic factors [Ja- cobs et al., 2013]. In the second phase of inflammation (chronic phase), chronic inflammatory cells, particularly the macrophages and lymphocytes, enter the injured site. The role of macrophages and $\mathrm{T}$ helper lymphocytes should be highlighted. Macrophages have many important roles during bone healing. They not only phagocytize the necrotic tissues, micro-organisms, and hematoma, but also release several beneficial cytokines and growth factors that facilitate the transition from the inflammatory stage to the reparative phase of bone healing. There are at least 2 important inflammatory behaviors in response to exogenous cell/graft/scaffold/matrix implantation. In the type I response, the lymphocyte T helper type I cells trigger macrophage type I cells, which causes an inflammatory reaction to occur. This type results in graft/ cell rejection. In contrast, in the type II response, the type II T helper lymphocytes trigger macrophage type II activity, which is a remodeling reaction that causes graft/cell acceptance in the body [Schmidt-Bleek et al., 2014; Moshiri et al., 2015a,b]. Recent investigations have shown that allogeneic MSCs promote the polarization of monocytes into an anti-inflammatory M2 phenotype. This M2 differentiation induced by allogeneic MSCs may occur 
through the NF- $\kappa \mathrm{B}$ and STAT-3 pathways [Abumaree et al., 2013; Cho et al., 2014].

Although inflammatory response plays a crucial role in bone regeneration, prolonged and/or exaggerated inflammation is harmful and retards the bone healing process [Stroncek and Reichert, 2008]. Also, the precise effects of innate and adaptive immune systems and their products on bone healing, especially for temporal and spatial patterns, remain unclear. Some products/cytokines are reported to promote bone healing, while others have been suggested to inhibit the process. Transplanted MSCs not only have the capability to differentiate into osteoblasts, but they are also known for their immunomodulatory effect via a variety of mechanisms [Pittet et al., 2014]. MSCs can be polarized into either a proinflammatory or immunosuppressive phenotype based on tolllike receptors (TLRs). They are polarized into a proinflammatory phenotype by TLR4 stimulation, whereas TLR3 stimulation can polarize MSCs into an immunosuppressive phenotype determined by MSC1 and MSC2, respectively [Waterman et al., 2010]. MSC1 has a significant effect in reducing IL-6, tumor necrosis factor- $\alpha$ (TNF- $\alpha$ ), and IL- $1 \beta$ levels 3 days after fracture. This process leads to a better regeneration by limiting tissue injury and inhibiting the progression of fibrosis [Carrion and Figueroa, 2011]. It has been shown that the production of inflammatory cytokines, including TNF- $\alpha$, IL-6, IL-12p70, and IFN- $\gamma$, by macrophages is significantly suppressed by MSCs, while the production of antiinflammatory cytokines like IL-10 and IL-12p40 is increased. It seems that PGE2 is the key mediator for this process [Asami et al., 2013]. The antiapoptotic effect of MSCs could also accelerate the process of bone healing. It has been suggested that faster bone healing with MSC transplantation may be especially correlated with lower levels of TNF- $\alpha$ expression in the callus [Kovach et al., 2015]. This may favor bone formation since it has been reported that TNF- $\alpha$ can have proapoptotic effects on osteoblasts.

\section{MSCs and Angiogenesis}

As we know, angiogenesis is a very important factor for bone formation and it is logical to speculate that angiogenesis also contributes to bone regeneration and repair. In this regard, many studies have attempted to incorporate angiogenic factors, including vascular endothelial growth factor (VEGF), basic fibroblast growth factor, insulin-like growth factor, platelet-derived growth factor, and bone morphogenetic proteins (BMPs) into scaffolds to improve the bone healing process [Chen et al.,

Role of MSCs in Bone Regenerative Medicine
2004; Simmons et al., 2004; Formiga et al., 2010]. The process of angiogenesis involves a complex interaction between endothelial cells and the corresponding microenvironment, including endothelial cell survival, proliferation, migration, tube formation, and maturation. In previous in vivo studies, the angiogenic activity of MSCs has been suggested to contribute to their regenerative capability [Smadja et al., 2012; Manieri et al., 2015]. The angiogenesis could be increased with the help of their paracrine signal. The microenvironment of the damaged tissue changes due to the angiogenesis, which then benefits osteogenesis [De Luca et al., 2011]. Some biomatrices, such as platelet-rich fibrin (PRF), play critical roles as a biological niche in stimulating the resident MSCs in the angiogenesis process. PRF (fibrin sealant or fibrin glue) is the second-generation plasma-rich plasma (PRP), which is an improved version of the traditionally prepared PRP. PRF significantly enhances the healing of soft and hard tissues and is widely used in regenerative dentistry. The PRF not only enhances the healing process through reducing bone resorption, but it also promotes neoangiogenesis in the defect site of oral bone [Marrelli and Tatullo, 2013]. It has been shown that the angiogenic activity of PRF is due to the slow and steady release of growth factors such as VEGF, which is primarily responsible for endothelial cell proliferation via the extracellular signal-regulated kinase activation pathway [Roy et al., 2011].

\section{MSC Homing and Recruitment to Bone Defects}

Many challenges are involved in the healing of criticalsized bone defects (CSDs). In bone, CSD is the term used for any orthopedic defect that will not heal without intervention and where nonunion would subsequently occur [Poser et al., 2014]. Basically, there are 3 main reasons for the occurrence of nonunions, including a lack of MSC migration into the defect site, insufficient numbers of osteoblast progenitor cells (MSCs) in the CSD, and failure to differentiate into osteoblasts or the wrong differentiation of MSCs [Wang et al., 2009]. As the first step of the chain in the treatment of nonunions, many researchers attempt to recruit MSCs to the defect site. The exact mechanism of MSC homing to the injury site is still not clear; however, chemotactic factors released at the site of the bone defect must play an essential role in MSC homing and recruitment.

It is known that MSCs express at least 19 chemokine receptors [Li et al., 2012]. Specific chemokine receptors (e.g., CCR1, CCR7, CCR9, CXCR4, CXCR5, and CXCR6) are important mediators in this matter, and among them CXCR4 and its ligand (CXCL12 or stromal-derived factor

Cells Tissues Organs 2017;204:59-83 DOI: 10.1159/000469704 


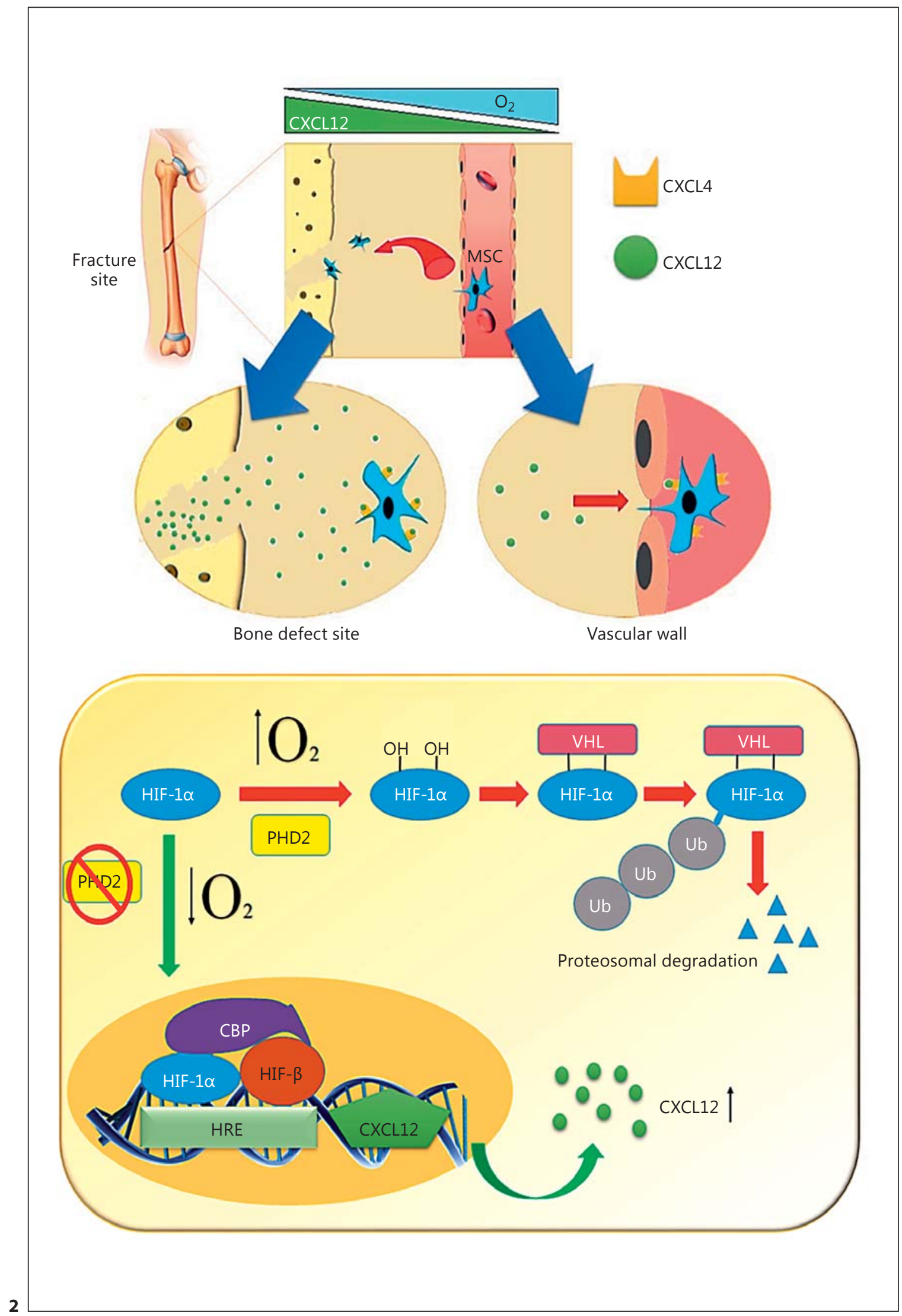

(For legend see next page.) 
1; SDF1) are the most widely investigated mediators in the MSC recruitment process [Kitaori et al., 2009]. A localized hypoxic condition occurs in the initial stage of fracture due to vascular damage that acts as a useful recruitment factor and regulatory stimulus for MSCs and other progenitor cells [Mehta et al., 2012; Toupadakis et al., 2012]. It has also been suggested that new bone formation occurs under hypoxic conditions [Olmsted-Davis et al., 2007]. Hypoxia can express special genes that increase cell survival under low oxygen tension and induce the reestablishment of blood vessels for oxygen delivery [Papandreou et al., 2006]. In addition, hypoxia by the expression of the hypoxia-inducible factor 1- $\alpha$ (HIF-1 $\alpha$ ) subunit transcription factor may induce the upregulation of SDF1 and ultimately regulate the homing of progenitor cells. The SDF1/CXCR4 (CXC chemokine receptor R4) axis is thought to be a master mediator of MSC recruitment and migration [Yellowley, 2013]. Because of the hypoxic condition at the injured (fracture) site, it is possible that the expression of chemokines such as SDF1 is regulated by hypoxia and HIF-1 $\alpha$. The homing of leukocytes and their role in transporting hematopoietic precursors in tissues are very similar to mechanisms that govern the migration of MSCs [Trautmann et al., 2014] (Fig. 2). It has been discovered that mobilization of MSCs to the site of fracture, where they are thought to contribute to the regeneration of bone, is mainly facilitated through paracrine support of angiogenic factors (e.g. VEGF, EGF). Furthermore, secretion of angiogenic factors in injured tissue could be due to the activation of HIFs [Mallela et al., 2013]. MSCs can also recruit the other MSCs or progenitor cells towards the injury/defect site via paracrine effects [Shao et al., 2015].

Some studies have focused on the recruitment of MSCs to the bone defect site for treating the nonunions. Das et al. [2014] showed that FTY720 (a small molecule) enhances MSC recruitment to the calvarial defect of rats, thus promoting skeletal repair. They suggested that sustained release of FTY720 from injected microspheres

Fig. 2. MSC homing to the fracture site. HIF-1a may increase the transcription of CXCL12 (SDF1) production in the cells of damaged bone. In normoxia conditions, HIF-1a is hydroxylated by the activity of prolyl hydroxylase domain protein 2 (PHD2), leading to HIF-1 $\alpha$ binding to the von Hippel-Lindau protein (VHL) and subsequent ubiquitination (Ub) and proteasomal degradation. Otherwise, in hypoxia $\left(\right.$ low $\left.\mathrm{O}_{2}\right)$, due to a reduction of PHD2 activity, HIF-1 $\alpha$ levels are stabilized and migrate into the nucleus to form a complex with HIF-1 $\beta$. HIF- $1 \alpha$ then binds to the hypoxiaresponsive element (HRE) on the promoter of the CXCL12 gene used alone or in combination with rhBMP-2 improves the recruitment of MSCs and subsequently increases bone repair. Zwingenberger et al. [2014] showed that SDF-1 $\alpha$ mediates stem cell mobilization and enhances BMP-2-induced bone regeneration in CSDs. They implanted adenovirally activated fat tissue grafts expressing SDF-1 $\alpha$ and/or BMP-2 at the defect site in the treatment group. CT-scans and histological analysis confirmed a higher degree of bone healing in the BMP-2 and SDF-1a combined group compared with the negative control group. In this area, another investigation showed that cobalt can activate HIF- $\alpha$, through which it contributes to the recruitment of MSCs for the initiation of the bone healing process [Wu et al., 2012]. With these promising results, endogenous MSC recruitment into the bone injury/defect site via small molecules or protein mobilizing factors could be another interesting field for researchers working on stem cell-based therapy in bone regeneration.

\section{MSCs and Differentiation of Host Cells}

Although MSCs have great potential to differentiate into various cell types, such as osteoblasts, and it has also been hypothesized that MSC transplantation would induce tissue regeneration by replacing cells in the injured site, the incidence of MSC engraftment has remained surprisingly low. Accumulating evidence indicates that the general therapeutic effects of MSCs are due to their ability to support a regenerative microenvironment rather than their capacity to differentiate and incorporate into the host tissue [Horwitz et al., 2002; Amin et al., 2014]. As previously mentioned, MSCs reduce the TNF- $\alpha$ level at the injured site. Another important effect of TNF- $\alpha$ is the blockage of osteoblast differentiation, which occurs by inhibiting the expression of 2 essential transcription factors for bone formation: Runx2 and its downstream target, osterix [Nanes, 2003]. Therefore, MSCs make an indirect contribution to osteoblast cell differentiation and bone regeneration. An interesting experimental study showed that transplanted MSCs contribute to fracture healing by with the cooperation of the transcriptional coactivating CREBbinding protein (CBP). This cascade can drive the upregulation of CXCL12 levels at the site of injury and promotes the migration of MSCs from the blood circulation to the defect site. The CXCL12 ligand binds to its receptor CXCR4 on circulating cells and converts cell surface integrins to a high-affinity state. This process is necessary for the binding of MSCs to vascular endothelial cells. MSCs then migrate through the endothelium towards the CXCL12 gradient. This process of chemokine-mediated cell extravasation is very similar to leukocyte transmigration.
Cells Tissues Organs 2017;204:59-83

DOI: $10.1159 / 000469704$ 


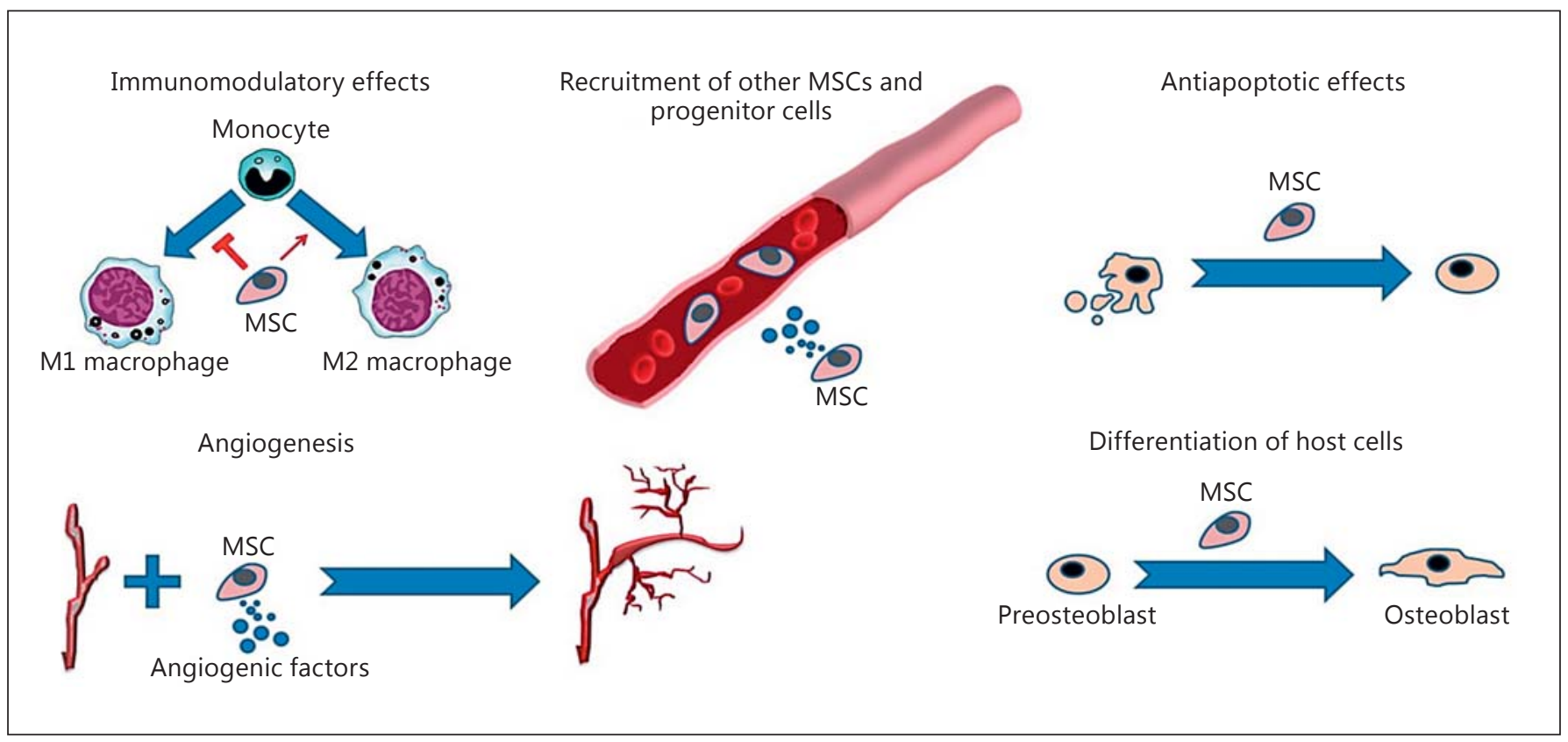

Fig. 3. Some mechanisms of MSC action on bone reconstruction and repair. The beneficial effects of MSCs include immunomodulatory effects, stimulation of angiogenesis, antiapoptotic effects in osteoblastic lineage cells, recruitment of host MSCs/progenitor cells, and stimulation of their differentiation into osteoblasts.

expressing BMP-2, which induces bone and cartilage formation [Granero-Moltó et al., 2009]. Some of the mechanisms of MSC action on bone regeneration and repair are illustrated in Figure 3.

\section{Delivery Methods of MSCs for Bone Repair}

So far, several different approaches have been utilized to deliver MSCs into the injured area of the bone (i.e., bone defects) [Bernardo et al., 2007; Sorrell et al., 2009; Lee et al., 2010; Achille et al., 2011]. The most common method for using MSCs is direct injection [Chabner et al., 2004]. Some studies have also shown that seeding MSCs on biocompatible scaffolds could be an attractive candidate for treating nonunion fractures [Oryan et al., 2014b]. In general, MSCs can be applied through systemic and local injections or by tissue engineering approaches.

\section{Systemic Injection Approach}

Systemic injection of MSCs has been used in the treatment of osteoporosis and fracture healing for many years [Huang et al., 2015]. Several factors are involved in order to achieve more successful results from cell therapy in bone healing. These include the vehicle and type of cells, cell concentration, differentiating status of the cells, treatment period, and route of administration [GraneroMoltó et al., 2009]. Bone marrow-derived MSCs and adipose tissue-derived MSCs (ADMSCs) are the most applicable type of MSCs that have been used in bone regenerative medicine. Among these, the stromal vascular fraction (SVF) is a component of adipose tissue that has attracted much attention recently, specifically for the use of this fabulous extraction in bone and cartilage defects [Jurgens et al., 2013]. SVF of adipose tissue is a rich source of preadipocytes, MSCs, different types of progenitor and inflammatory cells, and cytokines, which are extracted by the processing of body fat [Gentile et al., 2012]. Evidence from experimental and clinical studies has shown that SVF is more effective in bone and cartilage healing than ADMSCs alone. It is believed that the more advantageous effects of SVF may be a reflection of different growth promotion factors and cytokines, which not only support the proliferation, differentiation, and viability of ADMSCs, but also play a critical role in the tissue repair process [Pak et al., 2014]. SVF can be easily collected and enriched with platelet-rich plasma [Moshiri and Oryan, 2013]. In addition, ADMSCs in SVF can be activated by photostimulation with low-level lasers and light-emitting diodes [Peng et al., 2012].
66

Cells Tissues Organs 2017;204:59-83 DOI: $10.1159 / 000469704$
Oryan/Kamali/Moshiri/Baghaban Eslaminejad 


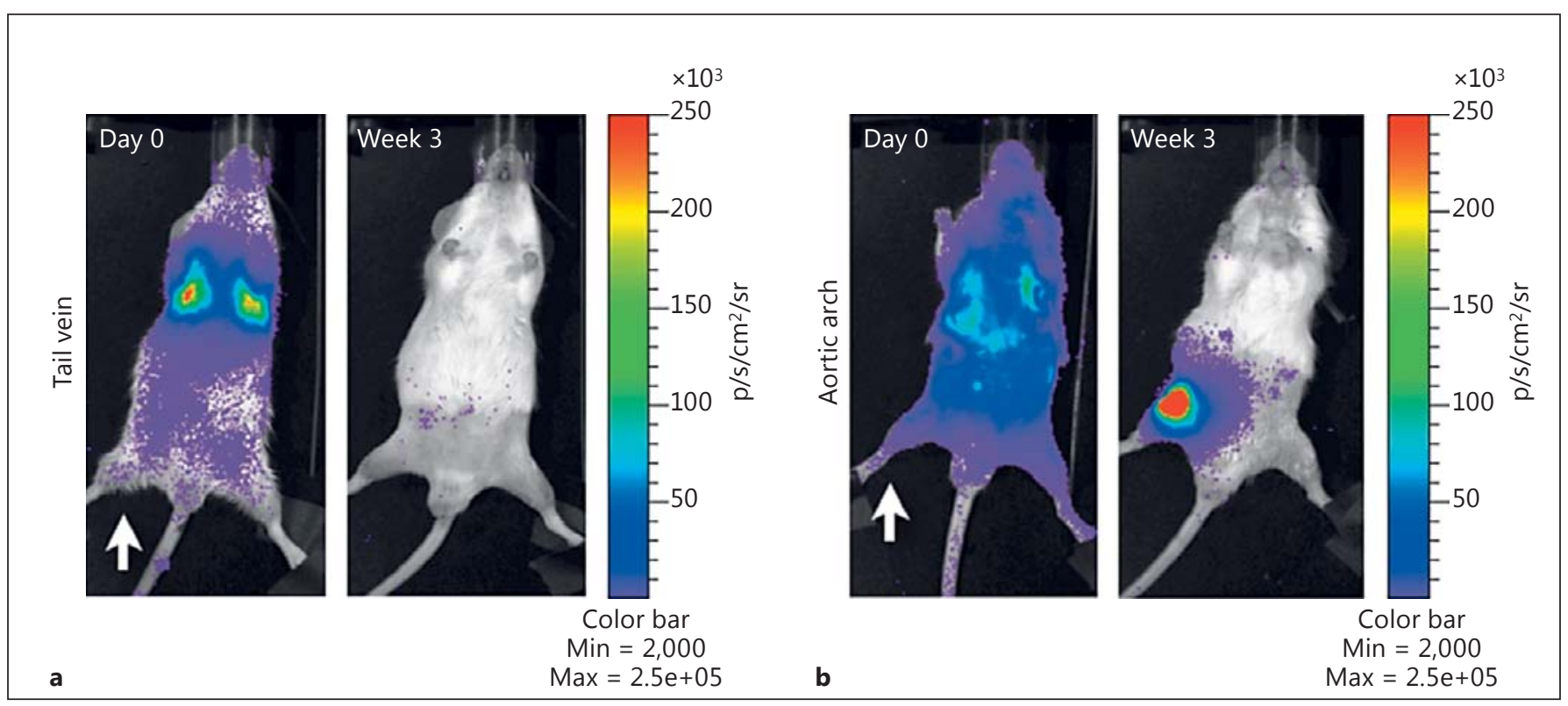

Fig. 4. Bioluminescence imaging of the IV and IA route of cell delivery in rats. Rats were irradiated unilaterally (white arrow) before IV (a) or IA (b) injection with $1 \times 10^{6}$ BMC9 MSCs expressing a luciferase reporter [Kean et al., 2013]. Copyright ${ }^{\complement} 2013$ Thomas J. Kean et al. This is an open access article distributed under the Creative Commons Attribution License, which permits unrestricted use, distribution, and reproduction in any medium, provided the original work is properly cited.

Similar to drug studies, there is an effective cell dose (ECD) for stem cell therapy, which is defined as the minimum cell number required to discern a remarkable therapeutic effect [Horwitz et al., 2002]. In clinical trials that have focused on bone regenerative medicine, the MSC dose per person is determined as a mean of $1.86 \times 10^{8}$ cells, or is based on body weight, calculated as a mean of $6.64 \times 10^{6} \mathrm{cells} / \mathrm{kg}$. However, there is no precise available ECD for the treatment of bone defects and disorders, meaning further studies are needed to illustrate a guideline in this regard.

It is important to select an appropriate route of administration for MSC therapy in order to improve bone healing. Intravascular injection of MSCs (including intravenous, IV, and intra-arterial, IA, cell delivery) has been used by many clinicians in bone defects and some promising results have been reported [Horwitz et al., 1999, 2001; Le Blanc et al., 2005]. Intravascular delivery of MSCs is the most common systemic method that is minimally invasive and has the potential for a broad distribution of cells throughout the body. Despite the suggested beneficial effectiveness of an IV injection method on bone repair, some drawbacks have been reported previously, such as significant entrapment of cells after passing through the lungs and formation of vascular microemboli [Castelo-Branco et al., 2012]. This effect in IV delivery of MSCs is called the pulmonary first pass effect [Fischer et al., 2009]. However, some investigations have suggested that MSCs trapped inside the lungs can potentially have therapeutic effects [Lee et al., 2009; Choi et al., 2011; Roddy et al., 2011]. Alternatively, MSCs can be systemically delivered by IA injection that overcomes the drawbacks of an IV delivery method. The pulmonary first pass effect of IV injection is bypassed by an IA route of administration. In addition, the ECD can be decreased by simply switching from IV to IA delivery due to the bypassing of the lungs and lower risk of cellular embolism. However, cellular embolism has also been reported with the IA delivery route of bone marrow stromal cells (BMSCs) in rats, which is related to the cell dose and infusion velocity [Cui et al., 2015]. Overall, use of a local delivery route for MSC transplantation has been suggested because many researchers believe that after systemic infusion virtually all MSCs are trapped in the lungs and rapidly disappear. The occurrence of some cells in extravascular spaces is most likely due to the vascular leakage created by the injury. A comparison of IV and IA delivery of MSCs is provided in Figure 4. 


\section{Direct Local Injection Approach}

In nonunion fractures, MSCs are usually harvested by bone marrow aspiration from a donor site (iliac crest, sternum, and tibia) and injected at the site of the bone defect. This method has been developed as a system called "bone marrow aspirate concentrate" (BMAC), which was so termed due to the aspirated mixture containing many MSCs [Murrell et al., 2015]. Several clinical studies have shown the effectiveness of a direct injection (local delivery by simple injection) approach in promoting bone regeneration [Connolly, 1998; Hernigou and Beaujean, 2002; Janowski et al., 2013]. In one study, BMAC was administered by a direct injection method with the aim of healing nonunion fractures in 20 patients; $80 \%$ of whom showed full recovery after 3 months [Elsattar et al., 2014]. Another study showed a positive correlation between mineralization and the quantities of BMAC used by percutaneous injection in 60 patients with nonunion of the tibia [Hernigou et al., 2006]. Other direct topical/local applications for MSC delivery include cell spray, gel, or subcutaneous injection with culture media or an appropriate carrier [Ennis et al., 2013]. The optimal cell concentration that should be used in a direct local injection approach is debated. Some researchers believe that the ECD for MSCs needs to be greater than 1 million cells per cubic centimeter of tissue to be effective in bone repair [Young et al., 2014]. However, despite the ECD information required for a local injection method, for induction of successful tissue regeneration a local delivery of MSCs should be combined with a systemic injection method. In general, systemic delivery approaches are more advisable for the treatment of deeper and multiple fracture sites, while local delivery of MSCs is more suitable for single and superficial bone defects [Raynaud and Rafii, 2013].

\section{Tissue Engineering Approaches}

In large bone defects where a significant amount of the bony tissue has been lost, a direct injection method has been found to be ineffective for MSC delivery and the acceleration of the bone healing process [Qin et al., 2014a]. Recently, it has been suggested that the controlled delivery of MSCs and factors that promote healing within biomaterial carriers (hydrogel, scaffold, etc.) can increase and accelerate functional new bone formation. There are 3 main tissue approaches for MSC-based cell delivery systems: (1) delivery of cells within injectable or prefabricated scaffolds, (2) codelivery of cells with osteoinductive growth factors or coculture with other cell types, and (3) delivery of cells within a 3D dynamic environment.
Basically, a functional prefabricated bone requires 3 elements: scaffolds or carriers (a 3D support), endothelial growth factors (stimulation of neovascularization and provision of blood supply), and MSCs or other growth promotion factors (stimulus for osteoinduction and recruitment of endogenous MSCs). An ideal scaffold/carrier should have 4 characteristics, including osteogenesis, osteoincorporation, osteoinduction, and osteoconduction [Oryan et al., 2014b]. Also, it should have a favorable cellular attachment capability and support colony formation. Biocompatibility is one of the primary characteristics of any scaffold, which is reflected by their ability to support a normal endo/exogenous cellular metabolism without any toxic effects [Amini et al., 2012]. Another important criterion for designing an ideal scaffold/carrier is the mechanical properties. These should match the host bone mechanical properties as closely as possible [Mallick and Cox, 2013]. In order to achieve successful diffusion (for accruing important nutrients, oxygen, and to remove cellular waste products), interconnected porosity is a necessity for scaffolds where pore size should be at least 100 $\mu \mathrm{m}$ in diameter [Bose et al., 2012]. The optimal scaffold pore size for bone tissue engineering is $200-350 \mu \mathrm{m}$ [Murphy et al., 2010]. Another crucial factor for prefabricated scaffolds/carriers is bioresorbability, which has been described as its ability to degrade with time in vivo, preferably at a controlled rate and eventually creating space for the generation of new bone and remodeling. The degradation time of the prefabricated bones should vary based on applications such as $2-4$ months for long bone defects, or 3-6 months in oral and craniofacial bone reconstruction [Williams, 2008]. The harvesting of MSCs is also a critical issue in TERM and it should be easy, inexpensive, and available. BMSCs are the most popular MSCs that can be easily harvested from the patient and widely used in long bone repair and regeneration. Using a newly discovered MSC lineage and an easily harvestable adult stem cell, such as dental pulp stem cells (DPSCs), introduces an interesting option in repairing bone defects of oral and dental tissues [Tatullo et al., 2015a]. These cells possess phenotypic characteristics similar to those of BMSCs, and they have the ability to self-renew and differentiate into multiple cell lineages, which are able to form the dentin-pulp structure when transplanted into immunocompromised animal models [Tatullo et al., 2015b]. In addition, DPSCs participate in the repair and regeneration of nondental tissues; in fact, these cells can differentiate into various types of cells, including neuron-, hair follicle-, hepatocyte-, and cardiomyocyte-like cells. Another source of MSCs easily isolated from dental
68

Cells Tissues Organs 2017;204:59-83

DOI: $10.1159 / 000469704$
Oryan/Kamali/Moshiri/Baghaban Eslaminejad 
pulp is stem cells derived from human exfoliated deciduous teeth, or SHEDs. Similar to DPSCs, these cells have been identified as a novel population of postnatal stem cells which could be induced to differentiate into odontoblasts, osteoblasts, myocytes, adipocytes, and neuron-like cells. Dentin and bone could be formed when the cells are transplanted with bioactive materials in vivo [Tatullo et al., 2015c].

MSC Delivery within Injectable or Prefabricated Scaffolds

The simplest method for MSC delivery in a local area with good efficacy is provided by scaffolds or special 3Dstructured carriers without the coadministration of exogenous growth factors. Numerous studies have formulated MSCs with natural and synthetic materials [Guo et al., 2009; Yang et al., 2009; Chan et al., 2010]. However, injectable ceramic-based carriers consisting of MSCs and biocompatible hydrogels may be a good option as a carrier for bone regeneration due to the osteoconductive characteristics of seeded MSCs as well as other advantages, such as injectability [Park et al., 2011]. On the other hand, lack of adequate mechanical pressure bearing in the mentioned carriers was a big challenge that should be considered especially in large bone defects that require more solid structures [Amini et al., 2012].

In one study, rat MSCs cultured on calcium phosphate material (ceramic component) and chitosan (hydrogel component) composites showed a severalfold increase in ALP activity in comparison to FDA-regulated calcium phosphate-based scaffolds and tissue culture plastic in vitro, indicating a special differentiation into an osteoblastic lineage [Moreau and Xu, 2009]. Another in vivo implantation of the porous composite scaffolds within a critically sized calvarial defect in a rat showed near complete osseous closure of the defect over 6 weeks [Lee et al., 2011].

The surface properties of a biomaterial have an important influence on their bioactivity and play critical roles in modulating cellular events. Considerable efforts have been made to increase the bioactivity and biocompatibility of TERM architectures via surface engineering and surface functionalization to provide an extracellular matrix (ECM)-mimicking environment in order to achieve better cell adhesion and tissue ingrowth. It has been shown that some silicon nanoporous and mesoporous matrices have the ability to differentiate DPSCs towards the osteogenic phenotype. The functionalization of a silicon nanoporous scaffold with (3-aminopropyl)trimethoxysilane and toluene was shown to support the

Role of MSCs in Bone Regenerative Medicine growth of DPSCs, which could be used in osteogenic differentiation [Marrelli et al., 2015a]. Another study showed that the physicochemical and biological properties of the mesoporous bioactive glass modified $\beta$-tricalcium phosphate (TCP) scaffolds, which were significantly improved when compared to the $\beta$-TCP scaffolds without the mesoporous bioactive glass nanolayer. The results of that study also suggested that incorporation of nanostructures and bioactive components into the bone bioscaffolds synergistically plays a key role in improved bone formation [Zhang et al., 2015].

\section{Codelivery of MSCs with Other Cell Types or}

Growth Factors

To increase the osteogenic efficacy of MSCs, they can be chemically or physically manipulated in vitro to induce predifferentiation into a specific lineage of osteogenic cells. Most commonly, an osteogenic medium with rich components, including dexamethasone, ascorbic acid, and $\beta$-glycerol phosphate, is used to increase osteoblastic differentiation of MSCs in vitro [Amini et al., 2012]. The conventional culture medium can sometimes also be supplemented with growth factors like BMPs and TGF- $\beta$ (transforming growth factor- $\beta$ ) to enhance their differentiation towards osteoblasts. The major problem is that MSC proliferation is greatly inhibited by their early induction down the osteogenic lineage and causes a significant reduction of viable MSCs for delivery. Also, this method requires large amounts BMP and TGF- $\beta$ to maintain the differentiated MSCs because of the short half-life of the growth factors. Therefore, this method is not practical according to the cost-benefit analysis.

Recent strategies have suggested the codelivery of MSCs with other cell types or growth factors in various delivery vehicles. The incorporation of growth-promotive factors is used to stimulate the differentiation of transplanted MSCs and enhance their activity as well as recruit undifferentiated osteoprogenitor cells into the vehicle. Until now, numerous investigations have shown the regenerative potential of growth factors and MSC codelivery in vitro and in vivo [Kim et al., 2007, 2010; Terella et al., 2010]; however, the synergistic effect of growth factors for a significant increase in bone formation is still unclear. Codelivery of MSCs with other cell types, such as endothelial cells and osteoblasts, may be another interesting option for increasing the osteogenic efficacy. Crosstalk between MSCs, osteoblasts, and endothelial cells is vital to the formation of new bone as well as the process of angiogenesis [Grellier et al., 2009]. In this regard, MSC and endothelial cell interaction leads

Cells Tissues Organs 2017;204:59-83 DOI: $10.1159 / 000469704$ 
to local release of VEGF and BMP-2, which promotes angiogenesis and osteoblastic differentiation, respectively. Numerous in vivo and in vitro studies have shown the positive effect of MSCs, endothelial cells, and osteoblast codelivery on vascularization and osteogenic differentiation in various scaffolds [Sun et al., 2007; Tao et al., 2009; Xue et al., 2009]. However, there are conflicting views regarding the application of osteogenic differentiation before or simultaneously with the MSC transplantation. Not only does it decrease the proliferation rate of MSCs, but more importantly it directs the stem cell that is in the BMSC population into osteogenic cells only; in other words, the skeletal stem cell does not self-renew and is lost. This becomes significant for long-term efficacy. Bone must turnover with time, and if the skeletal stem cell is lost this turnover fails in the long term [Robey, 2011].

Delivery of Cells within a 3D Dynamic Environment

The extracellular environment can regulate the fate of MSCs via exposing them to various chemical, physical, and mechanical signals [Tatullo et al., 2016]. In order to mimic the natural transport and biomechanical conditions in human/animal bodies, MSCs may be cultured within a dynamic 3D environment such as conventional bioreactors [Rauh et al., 2011; Yeatts and Fisher, 2011]. A novel strategy for fabrication of a dynamic 3D environment involves the manufacturing of bioactive ECM coatings on biologically inert vehicles to present biological signaling cues for the bone healing process. A newer approach in tissue engineering that attempts to simulate the situation of the natural ECM is a special hydrogel with the property of light-activated immobilization of biomolecules. In this hydrogel, a controlled release of the biomolecules, including various types of growth hormones and cytokines, etc., occurs under the control of photosensitive biofactors. Different biomolecules are released at different times to mimic as closely as possible the situation of the natural ECM [Luo and Shoichet, 2004]. However, the native ECM consists of a very complex arrangement of collagen, glycoproteins, and a variety of growth-promotive factors which continuously change in a real regeneration process; thus the replication of the same ECM is almost unthinkable [Dennis et al., 2015]. Recently, investigations have focused on designing new vehicles by using the decellularized matrices (natural ECM). Numerous studies have shown the promising osteogenic effects of MSC-laden decellularized ECMs in the absence of osteogenic cell culture supplements or any growth factors [Datta et al., 2006; Pham et al., 2009; Liao et al., 2010]. One study showed that MSCs seeded with ECM construct and cultured in medium either with or without dexamethasone revealed similar amounts of calcium deposition after 16 days. Moreover, a significant increase in the number of MSCs over time was observed in the MSC-seeded ECM construct group in comparison with the culture medium group [Thibault et al., 2010].

Surface roughness and the topology of bone scaffolds/ matrices can be the first physical cue for the seeded MSCs. In fact, utilization of different surfaces can modify cell behaviors. Tatullo et al. [2016] showed that physical factors of the cell culture environment were able to affect the distribution and shape of the MSCs isolated from dental pulp (DPSCs), and were able to regulate their differentiation into osteogenic phenotypes. The cells seeded on the hydrogel scaffolds derived from bovine bone ECM tended to grow in clusters, and created a round structure that increased the contraction of the hydrogel scaffold. They also found that application of hydrogel scaffolds fabricated with bovine bone ECM influenced the cell distribution and cell morphology, based on their matrix stiffness, and also enhanced the odontogenic and osteogenic differentiation of DPSCs in comparison to the conventional polystyrene tissue culture plates. Cell morphology on different surfaces reflects the cytoskeletal organization, such as microtubules and actin filaments. These changes in cytoskeletal organization and mechanical properties are dependent upon integrin clustering which can significantly lead to osteogenic differentiation [Mathieu and Loboa, 2012]. Therefore, the different mechanical properties of scaffolds and the surfaces matrices influence cytoskeletal changes and play a critical role in odontogenic or osteogenic differentiation [Yim et al., 2010].

\section{Clinical Application of MSCs for Bone Healing}

Until now, MSCs have been used in bone tissue engineering in order to improve the therapeutic options for enhancing bone repair. MSCs have been studied in a wide variety of animal species, including mice, rats, rabbits, dogs, and horses [Jafarian et al., 2008; De Schauwer et al., 2013]. Similar to humans, the MSCs can be isolated from these animals, making animal models useful for understanding the mechanisms and applicable approaches in the clinical setting. Clinical trials that have used MSCs for treating bone injuries can be categorized into 2 major groups based on the site of MSC application: (1) oral and
70

Cells Tissues Organs 2017;204:59-83 DOI: $10.1159 / 000469704$
Oryan/Kamali/Moshiri/Baghaban Eslaminejad 
maxillofacial defects, and (2) long bone defects. Using MSCs, several strategies have been utilized to promote bone repair in the clinical setting, including the local or systemic injection of MSCs with or without hydrogels, fabricated scaffolds with MSCs, and a cell sheath layer (free scaffold strategies).

\section{MSCs for Treating Oral and Craniofacial Bone \\ Injuries}

Oral and maxillofacial surgery is a regional specialty, focusing on treatment of the head, neck, face, jaws, and the hard and soft tissues of oral (mouth) diseases and defects. In oral and maxillofacial surgery, inserting implants in a reconstructive approach is a routine surgical procedure but has not always been associated with satisfactory results. For instance, in severely resorbed posterior maxilla, the procedure may be complicated due to the lack of cortical bone, low density of cancellous bone, limited volume, and the mechanical properties of the resorbed bone [Mangano et al., 2014]. Moreover, implant placement success rates have been reported to be lower in the posterior upper jaw than in other regions [Monteiro et al., 2015]. When natural maxillary teeth are lost through progressive maxillary sinus pneumatization, which is associated with the formation of caudal recesses, the ridge (toothless area) gradually loses both height and width [Rokn et al., 2011]. Sinus augmentation or sinus lift is a surgical procedure that aims to increase the amount of bone volume in the molar and premolar area. This procedure is intended to add new bone between the jaw and the maxillary sinuses (in the caudal section of the maxillary sinus) [Sarkar and Lee, 2015]. Among the various techniques that are available to reconstruct deficient bone or fill a ridge, such as using a synthetic bone substitute like ceramics, bioglass, and glass ceramic compounds, autologous grafting is still a predictable and well-documented surgical approach [Tavakolinejad et al., 2014]. However, the major limiting factor for autogenous bone graft reconstruction is that the procedure is generally invasive and is associated with donor site complications, including infection, malformation, and pain [Sarkar and Lee, 2015]. In pediatrics, a large number of cases also have cleft lips and a palate that needs to be reconstructed with autologous bone implants. Unfortunately, these procedures involve many complications that could dramatically impact the speech and swallowing of the children [Zuk, 2008].

In recent decades, the application of the MSCs for treating oral and craniofacial bone defects has become more and more popular in the literature. To list a few,

Role of MSCs in Bone Regenerative

Medicine
MSCs have been incorporated with hydroxyapatite/TCP scaffolds for the reconstruction of calvarial and alveolar bone in mice and dogs [De Kok et al., 2003; Mankani et al., 2006], seeded into microporous gelatin scaffold for the regeneration of calvarial defects in mice [Krebsbach et al., 1998], combined with PLA-based scaffolds to repair cranial bone defects in rabbits [Bidic et al., 2003], and loaded on hyaluronan-based scaffold in order to regenerate orbital rim defects in pigs [Radice et al., 2000]. MSCs with or without scaffold and osteogenic factors have been used for many sinus augmentation surgeries in many clinical trials [Gimbel et al., 2007; Pelegrine et al., 2010; Sauerbier et al., 2010; Rickert et al., 2011; Sauerbier et al., 2011; Hermund et al., 2012; Kaigler et al., 2013]. In addition, MSCs have been used by different delivery approaches in other craniofacial defects caused by traumatic bone defect, osteomyelitis, and tumor resection (Table 2). Most clinical trials in oral and craniofacial bone repair have reported promising results [Gimbel et al., 2007; Pelegrine et al., 2010; Sauerbier et al., 2010; Rickert et al., 2011; Sauerbier et al., 2011; Kaigler et al., 2013]; however, no statistically significant results were found in one clinical trial [Hermund et al., 2012]. Such controversial results may be rooted in the various technical errors. For example, the autogenous bone MSCs were harvested from the atrophic tuberosity region that may contain low-quality MSCs for regeneration purposes. The conventional MSC cultivation and expansion procedure may have reduced the efficacy of regenerative effects. Such reduced efficacy occurs especially when other clinical trials apply BMACs directly and without any expansion process, or when the procedure is carried out without special bioreactors or high-tech facilities. Furthermore, the results of some studies that did not show proper bone formation may be due to low-quality starting material or inadequate culture conditions. The culture conditions used are vastly different from one laboratory to another, and this can have a dramatic impact on outcome.

Although MSCs continue to be used as applicable stem cells for the regeneration of oral and craniofacial defects, they present some drawbacks that should be recognized. Foremost, bone marrow harvesting is a painful procedure, especially for children with a massive cleft palate/lip. The yield of bone marrow harvest is also an issue. An in vitro amplification for harvested MSCs is almost a necessity due to the relatively low numbers of harvested cells ( $1 \mathrm{MSC} / 10^{4}-10^{6}$ stromal cells) [Kadiyala et al., 1997]. Because of these drawbacks, some publications have presented MSCs isolated form adipose tissue

Cells Tissues Organs 2017;204:59-83

DOI: $10.1159 / 000469704$ 
Table 2. Clinical trials using MSCs for oral and craniofacial bone tissue regeneration

\begin{tabular}{|c|c|c|c|c|c|c|c|c|c|}
\hline Reference & $\begin{array}{l}\text { Study } \\
\text { interval }\end{array}$ & Stem cell & $\begin{array}{l}\text { Tests, } \\
n\end{array}$ & $\begin{array}{l}\text { Controls, } \\
n\end{array}$ & Scaffold & Defect & $\begin{array}{l}\text { Follow- } \\
\text { up }\end{array}$ & Analysis & Outcome \\
\hline $\begin{array}{l}\text { Rickert } \\
\text { et al. [2011] }\end{array}$ & $\begin{array}{l}13-16 \\
\text { months }\end{array}$ & MSC & 12 & 12 & BBM & $\begin{array}{l}\text { sinus } \\
\text { augmentation }\end{array}$ & - & histomorphometry & $\begin{array}{l}\text { the test group showed } \\
\text { significantly more new } \\
\text { bone formation when } \\
\text { compared with the control } \\
\text { group }\end{array}$ \\
\hline $\begin{array}{l}\text { Hermund } \\
\text { et al. [2012] }\end{array}$ & 4 months & $\begin{array}{l}\text { autogenous } \\
\text { culture- } \\
\text { expanded MSC }\end{array}$ & $\begin{array}{r}10 \\
\\
\end{array}$ & 10 & $\begin{array}{l}50 \% \mathrm{AB}+ \\
50 \% \mathrm{BBM}\end{array}$ & $\begin{array}{l}\text { sinus } \\
\text { augmentation }\end{array}$ & 8 months & $\begin{array}{l}\text { histomorphometry, } \\
\text { histopathology, } \\
\text { bone densitometry }\end{array}$ & $\begin{array}{l}\text { none of the differences } \\
\text { between groups were } \\
\text { statistically significant }\end{array}$ \\
\hline $\begin{array}{l}\text { Sauerbier } \\
\text { et al. [2011] }\end{array}$ & $3-4$ months & MSC & 25 & 11 & $\mathrm{BBM}$ & $\begin{array}{l}\text { sinus } \\
\text { augmentation }\end{array}$ & - & histomorphometry & $\begin{array}{l}\text { new bone formation and } \\
\text { bone mineral density in } \\
\text { the test groups were } \\
\text { significantly higher than in } \\
\text { the control group }\end{array}$ \\
\hline $\begin{array}{l}\text { Pelegrine } \\
\text { et al. [2010] }\end{array}$ & 6 months & MSC & 15 & 15 & - & $\begin{array}{l}\text { alveolar } \\
\text { reconstruction }\end{array}$ & - & $\begin{array}{l}\text { histomorphometry, } \\
\text { histopathology, }\end{array}$ & $\begin{array}{l}\text { horizontal and vertical } \\
\text { bone loss was lower and } \\
\text { new bone formation was } \\
\text { higher in the test group } \\
\text { when compared with the } \\
\text { controls }\end{array}$ \\
\hline $\begin{array}{l}\text { Kaigler } \\
\text { et al. [2013] }\end{array}$ & $\begin{array}{l}6 \text { or } \\
12 \text { weeks }\end{array}$ & MSC & 12 & 12 & CS & $\begin{array}{l}\text { alveolar } \\
\text { reconstruction }\end{array}$ & 1 year & $\begin{array}{l}\text { radiography, } \\
\text { micro-CT, } \\
\text { histopathology }\end{array}$ & $\begin{array}{l}\text { linear bone height was } \\
55.3-78.9 \% 6 \text { weeks after } \\
\text { treatment (control vs. test) } \\
\text { and } 74.6-80.1 \% \text { after } \\
12 \text { weeks }\end{array}$ \\
\hline $\begin{array}{l}\text { Gimbel } \\
\text { et al. [2007] }\end{array}$ & $\begin{array}{l}1 \text { day, } \\
1 \text { week, } \\
3 \text { weeks, } \\
6 \text { weeks, } \\
6 \text { months }\end{array}$ & MSC & 21 & 25 & CS & cleft palate & - & $\begin{array}{l}\text { comfort and } \\
\text { complications for } \\
\text { donor site }\end{array}$ & $\begin{array}{l}\text { best results in the test } \\
\text { groups followed by a tissue } \\
\text { engineering technique } \\
\text { with a resorbable collagen- } \\
\text { stem cell construct }\end{array}$ \\
\hline $\begin{array}{l}\text { Sauerbier } \\
\text { et al. [2010] }\end{array}$ & 4 months & MSC & 12 & 6 & BBM & $\begin{array}{l}\text { atrophied } \\
\text { maxillary sinus }\end{array}$ & - & $\begin{array}{l}\text { histomorphometry, } \\
\text { histopathology }\end{array}$ & $\begin{array}{l}\text { radiographic images and } \\
\text { histopathological } \\
\text { examinations showed that } \\
\text { new bone formation was } \\
\text { higher in the test group }\end{array}$ \\
\hline
\end{tabular}

MSCs, mesenchymal stem cells; BBM, bovine bone mineral; AB, allogenic block; CS, collagen sponge; CT, computed tomography.

as an attractive alternative for BMSCs [Hudson et al., 1995; Levi and Longaker, 2011]. Although, ADMSCs share certain features with BMSCs (for example the expression of connective tissue cell surface markers), their osteogenic potential has been demonstrated primarily by in vitro analyses and often with the help of growth factors such as BMPs. To date, there is no rigorous evidence that MSCs isolated from adipose tissue are inherently osteogenic. They may temporarily form bone when treated with BMPs, but the bone is not enduring when BMP-induced signaling disappears. In fact, Levi et al. [2010] reported that ADSCs induced bone formation by cells in the dura mater (via paracrine hedgehog signaling with calvarial osteoblasts), and did not make bone themselves.

\section{MSCs for Treating Long Bone Injuries}

In the literature to date, a review of clinical trials in long bone healing and repair provides very limited evidence of trustworthy data on bone tissue regeneration reported after in vitro cultivation of MSCs, and there is not any scientific evidence for the use of genetic manipulation technology (e.g., gene-modified MSCs). Unlike in animals, generally only BMACs have been used in human clinical trials [Hauzeur and Gangji, 2010]. For the first time, Connolly and Shindell [1986] used bone marrowderived MSCs in a case of nonunion. In a further report that was conducted between 1986 and 1995 (involving 15 years of research), bone marrow transplant was used for osteogenesis in 100 patients with nonunion tibial fractures, with a positive correlation apparent in 80 patients [Connolly, 1998]. In the prone position and under gen- 
eral anesthesia, bone marrow was aspirated in 3-5 mL aliquots. At the same time as the marrow aspiration, a second needle was placed into the site of the nonunion and $100-150 \mathrm{~mL}$ of BMA was directly injected. The second injection was performed in 2 cases without the reason being mentioned by the authors. Eventually, the healing time was reported to be between 6 and 10 months. For the first time, Horwitz et al. [1999] reported clinical responses of 3 children with severe osteogenesis imperfecta (OI) who underwent allogeneic mesenchymal bone marrow transplantation. OI is a genetic disorder that mainly affects the bones, making them brittle. MSC therapy can be used to reduce fracture rates in such skeletal abnormalities. The cells were injected intravenously after treatment with immunosuppressive drugs. A postoperative histological evaluation after 216 days and bone densitometry analysis showed a significant improvement in the bone structure [Horwitz et al., 1999]. In another study performed in 2005, the results of a retrospective study including 60 patients with tibial nonunion fracture were reported [Healey et al., 1990]. Under general anesthesia, $300 \mathrm{~mL}$ of bone marrow was aspirated from the donor site (iliac crest), then concentrated by centrifugation. The 50 $\mathrm{mL}$ of concentrated bone marrow was injected into the nonunion site. In 53 patients, bone formation (union) was obtained between 4 and 16 weeks after treatment. The number of injected MSCs was counted and a significantly lower number of MSCs was observed in the cases that showed failed repair. In a randomized controlled trial, the autologous osteoblast cells were obtained from a 4-week culture of 3-5 mL bone marrow aspirate. A mixture with $0.4 \mathrm{~mL}\left(12 \times 10^{6}\right.$ cells $)$ and fibrin was prepared and injected locally into the fracture site. Eventually, a significant fracture healing acceleration was observed. This is the only published clinical trial that has used differentiated MSCs in long bone fracture healing [Kim et al., 2009].

In the field of stem cell therapy, considerable clinical information about the myriad possibilities are available for consideration. Many registered international or national clinical trials have been conducted to investigate the role of MSCs in long bone defect healing. However, so far almost none of them have reported their results, with only a few providing initial information about their research. This review used available information in clinical trial databases such as the European Clinical Trials Database (https://www.clinicaltrialsregister.eu/), the ClinicalTrials.gov database (https://clinicaltrials.gov/), the International Standard Randomized Controlled Trial Numbers Register (http://www.isrctn.com/), and the

Role of MSCs in Bone Regenerative Medicine
Australian and New Zealand clinical trials registry (www. anzctr.org.au/). In order to show the current status of clinical MSC therapy for bone repair, the available clinical trials are listed in Table 3. All the clinical trials related with MSCs and long bone defects cited in clinical trial registries were included, and those labeled as "unknown status," "withdraw," or "not yet recruiting" were excluded. Finally, 16 clinical trials related to long bone fracture, delayed union or nonunion, and MSC therapy were identified that were cited in clinical trial registries as completed (10 of them) or recruiting patients. These trials used MSCs for treating long bone fracture/nonunion via different procedures, including direct injection/implantation of the MSCs with or without scaffolds/matrices. They can be classified into 3 groups to allow for a comparative analysis. The first group, with 4 clinical trials ( 3 completed), used local injection of MSCs without in vitro culture and expansion, and none of these trials have been published so far. The second group (5 clinical trials, 2 completed, none published) used expanded MSCs by local injection in the defect site. The third group consisted of 8 trials intending to test MSCs with bone substitutes. Just 1 among the completed trails has published the results [Liebergall et al., 2013].

Needless to say, the main criticism of these completed clinical trials is their failure to report results. This may reflect: (1) lack of expected results (e.g., beneficial effects of MSCs on bone regeneration), (2) inconsistency in results, (3) the need to conduct further phases of study, or (4) other unknown reasons. In addition, many of these trials do not offer enough information about their exact protocols, which would be necessary to repeat their work in other centers or organizations. However, because of the ambiguous evidence in these clinical trials and lack of published results, success with this therapy will remain controversial and disputed.

\section{Future Directions of MSC Therapy in Clinical Practice}

The molecular engineering of stem cells is an interesting area for researchers who try to combine gene therapy with stem cell therapy in order to get better regenerative properties. Over the past 2 decades, a gene delivery strategy for enhancing the function of MSCs has been developed [Izadpanah and Bunnell, 2008]. MSC gene delivery can be divided into viral and nonviral methods [Izadpanah and Bunnell, 2008]. Among the available viral methods, some viral vectors have been used widely by gene therapists, including oncogenic retroviral vectors, ade-

Cells Tissues Organs 2017;204:59-83

DOI: 10.1159/000469704 


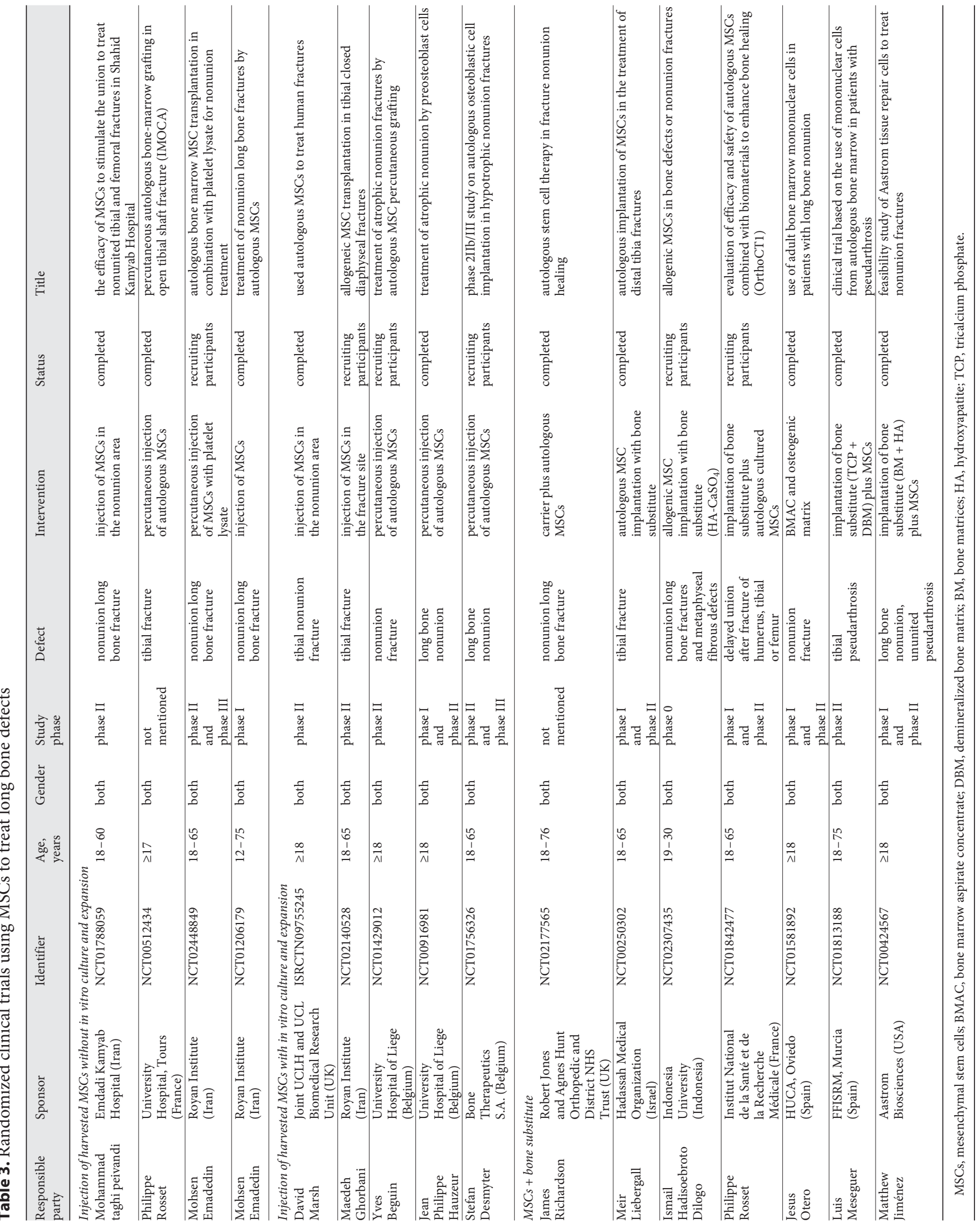




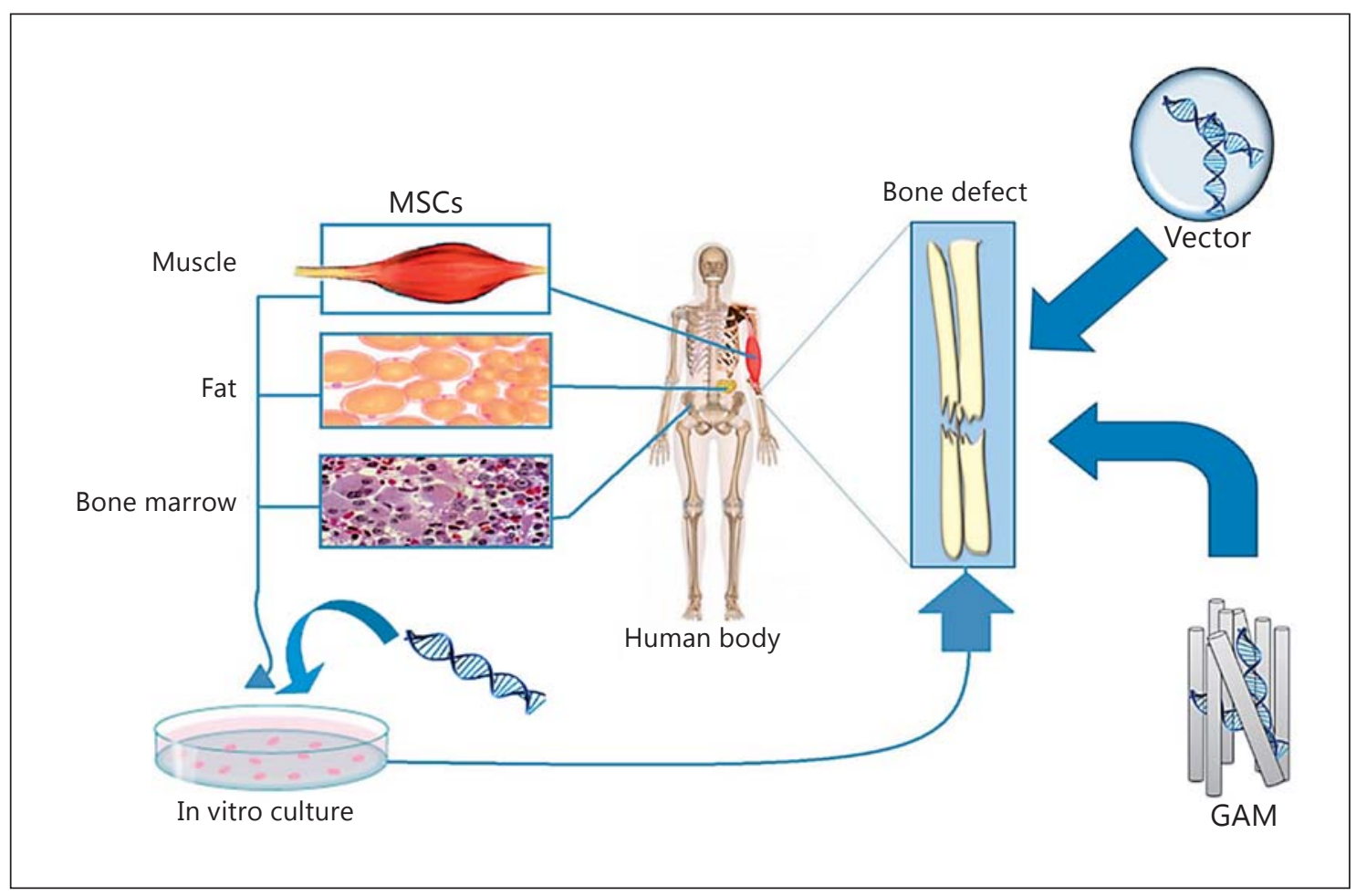

Fig. 5. Different approaches in gene-modified MSCs.

noviral vectors, lentiviral vectors, and adeno-associated viral vectors. The application of viral methods to transfer the desired gene into MSCs remains controversial. Although viral-based methods provide a long-term expression of the desired genes, they are not safe and may produce an immunological response or toxicological effects in the body [Abdul Halim et al., 2014]. Considering the translational aspect from bench to bedside, many attempts have been made to develop a safe and efficient nonviral gene delivery method that does not have the disadvantages of the viral approach. The most important nonviral methods for gene transfer into MSCs include liposome-based methods, calcium phosphate techniques, and electroporation [Santos et al., 2011].

BMP family genes are the most commonly used in genetic manipulation of MSCs due to their better regeneration properties [Gamradt et al., 2006; Zhang et al., 2012]. He et al. [2013] evaluated the role of BMP-2 genetically engineered MSCs on the bone regeneration process in a critical sized calvarial bone defect model in rats. The transfected cells dramatically increased new bone formation and angiogenesis 5 weeks after surgery when compared to the nontransfected MSCs. Seamon et al. [2013] subcutaneously injected MSCs transduced with adenovi-

Role of MSCs in Bone Regenerative Medicine ral vector (Ad-VEGF + BMP-6) in rats. Analysis showed that only gene-transduced MSCs could induce osteogenesis in vivo, whereas adenoviral vector or nontransduced MSCs alone did not induce osteogenesis.

The osteogenic genes can also be transduced to MSCs using a gene-activated matrix (GAM). GAM is one of the tissue engineering approaches that consists of collagenous scaffold impregnated with plasmid DNA encoding osteogenic genes. When GAM is inserted into a bone defect, host MSCs entering the scaffold are transfected by plasmid and consequently secrete the osteogenic gene product. The usefulness of GAM in bone tissue regeneration was investigated by Umebayashi et al. [2015]. GAM with atelocollagen containing cDNA of BMP4 (pBMP4) or Runx2 (pRunx2) was transplanted into the cranial bone surface under the periosteum of F344 rats. At 2, 4, and 8 weeks after surgery, the results showed that the bone induction effect of GAM is dose-dependent and bone formation was detectable in specimens containing $1 \mathrm{mg}$ of pBMP 4 or pRunx 2 at 8 weeks.

Epigenetic regulation and RNA interference are major strategies routinely used to modify genes. Gordon et al. [2011] showed that loss of the PBX1 (pre-B-cell leukemia homeobox 1) gene from the osterix promoter is associ-

Cells Tissues Organs 2017;204:59-83 75 
Fig. 6. The gene delivery process for MSCs: (1) the carrier or nanoparticle is complexed with the target gene; (2) the carrier or nanoparticle is endocytosed to travel through the intracellular pathway; (3) the target gene enters the nucleus; (4) the target gene resides in the nucleus; (5) the RNA polymerase transcript target gene along with the cellular gene; (6) mRNA transcription of the target gene; and (7) mRNA translation into a specific osteogenic protein.

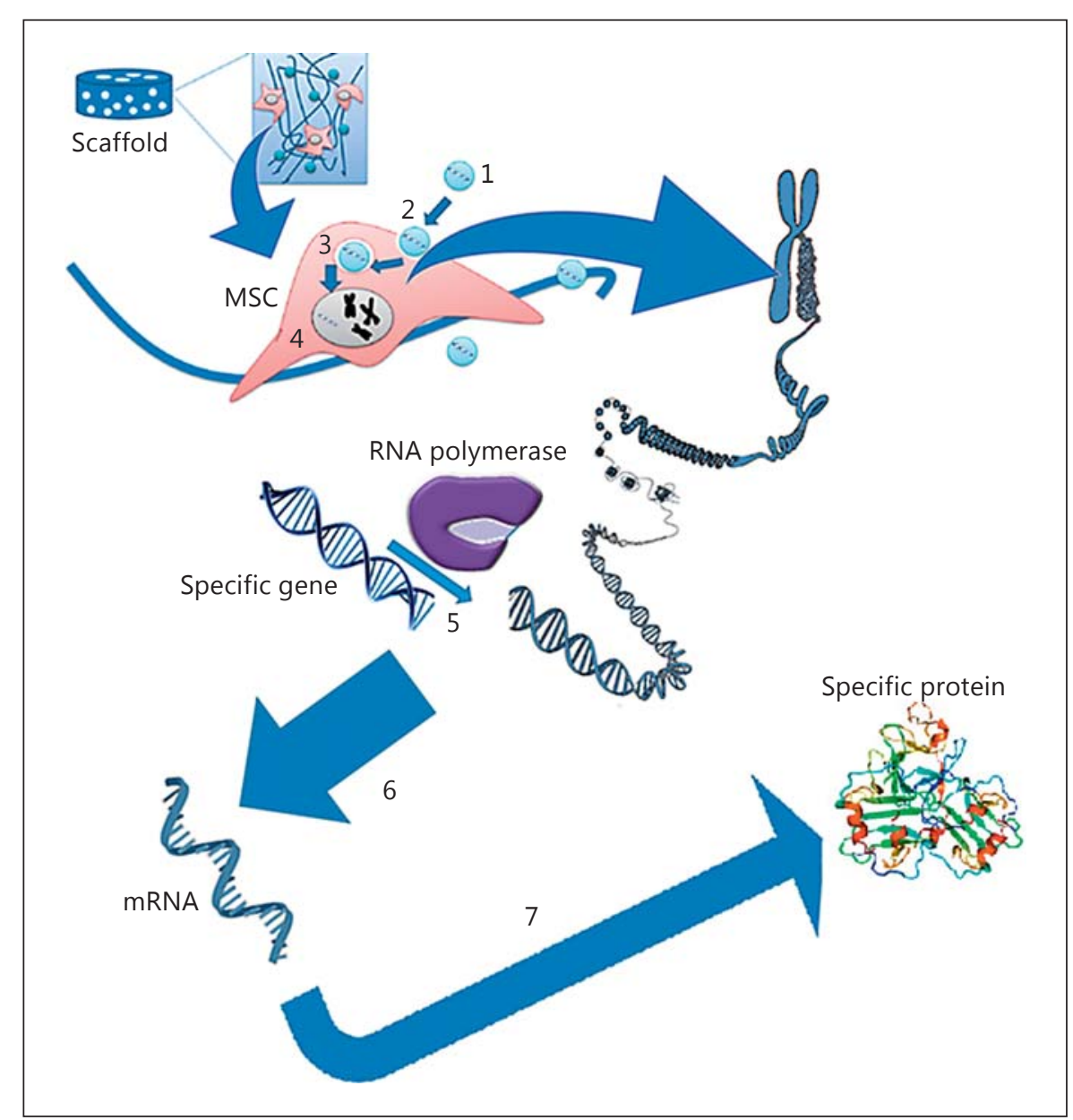

ated with an increase in the recruitment of histone acetylases (p300). Based on this result, it was proposed that PBX1 plays a central role in weakening the activity of the HOXA10 (homeobox A10) gene as an activator of osteoblast-related genes and functions to establish the appropriate timing of gene expression during osteogenesis. Furthermore, Zeng et al. [2012] found that knockdown of BMPR-2 by RNA interference inhibits osteogenic differentiation of ADMSCs. Although promising results have been generated in the experimental studies, gene-manipulated MSC transplantation for treating bone injuries in humans has limited application and its safety and efficacy need to be elucidated in the near future. In addition, developing clinical grade vectors is a very complex process and does not seem to be cost effective. Genetic modification strategies of MSCs for bone healing are shown in Figures 5 and 6.

\section{Conclusion}

The challenge for the upcoming decade of bone regeneration research is therefore to build on recent advances in our understanding of stem cells and our improved understanding of cellular and molecular therapeutic mechanisms of action in long bone delayed union/nonunion fractures. However, there is a significant clinical need to illustrate the exact mechanisms of MSCs in bone healing processes and evaluate their performance on large bone defects, delay/nonunion fractures, and oral bone regeneration. This is very important in order to obtain a detailed practical and comprehensive approach with maximum beneficial effect because an inappropriate or false approach can be disastrous. For instance, differentiation disorders in MSCs may lead to tumorigenesis or their differentiation into unwanted adult cells (such as the differentiation of MSCs into osteoblasts in cardiac implantation) [Meier et al., 2013]. To overcome these drawbacks, new technologies and a novel observation system that 
Table 4. A useful guide for MSC therapy research

\begin{tabular}{|c|c|c|c|c|c|c|c|}
\hline Patients & Comments & $\begin{array}{l}\text { MSCs } / \mathrm{mL} \\
\text { injected }\end{array}$ & $\begin{array}{l}\text { MSCs (total) } \\
\text { injected }\end{array}$ & $\begin{array}{l}\mathrm{MSCs} / \mathrm{cm}^{2} \\
\text { seeded on } \\
\text { scaffold }\end{array}$ & $\begin{array}{l}\text { MSCs total } \\
\text { in scaffold }\end{array}$ & $\begin{array}{l}\text { Scaffold } \\
\text { or graft } \\
\text { material }\end{array}$ & Status \\
\hline Child & $\begin{array}{l}\text { It would be inconceivable to put an infant or child through } \\
\text { MSC therapy because the metabolic and cell proliferation rates } \\
\text { are very high and may lead to tumorigenesis. However, some } \\
\text { studies have used MSCs in bone regeneration programs, to } \\
\text { treat osteogenesis imperfecta. These infused MSCs pre-and } \\
\text { postparturition with a sonography guidance procedure and } \\
\text { achieved some exciting results }\end{array}$ & - & $\begin{array}{l}\text { Varied from } 5 \text { to } \\
30 \times 10^{6} / \mathrm{kg} \text { at } \\
\text { prenatal } \\
\text { transplantation } \\
\text { and from } 2.8 \text { to } \\
10 \times 10^{6} / \mathrm{kg} \text { at } \\
\text { postnatal } \\
\text { transplantation }\end{array}$ & - & - & - & $\begin{array}{l}\text { Clinical } \\
\text { evidence }\end{array}$ \\
\hline Diabetic & $\begin{array}{l}\text { It is better to treat diabetic patients after controlling the } \\
\text { disease. Bone marrow MSC therapy in these patients provides } \\
\text { promising results for the treatment of nonunion fractures and } \\
\text { may be preferable in view of the high risk of major } \\
\text { complications after open surgery and iliac bone grafting. In } \\
\text { addition, the percentage of cured patients is much higher than } \\
\text { with iliac bone grafting }\end{array}$ & - & $61,000 \pm 18,000$ & - & - & - & $\begin{array}{l}\text { Clinical } \\
\text { evidence }\end{array}$ \\
\hline Osteoporotic & $\begin{array}{l}\text { In vivo study results demonstrate the usefulness of MSCs with } \\
\text { or without bioscaffolds in the management of osteoporosis. } \\
\text { These studies open a new possibility for utilizing MSCs to } \\
\text { treat osteoporotic patients }\end{array}$ & - & $3 \times 10^{6}$ & - & $3 \times 10^{6}$ & $\begin{array}{l}\text { TCP, } \\
\text { CA-S }\end{array}$ & $\begin{array}{l}\text { In vivo } \\
\text { study }\end{array}$ \\
\hline Cancer & $\begin{array}{l}\text { Normally, using MSCs in bone cancers like osteosarcoma is } \\
\text { contraindicated. MSCs are able to feed osteosarcoma cells via } \\
\text { their production and secretion of } l \text {-lactate. Also, they can } \\
\text { cause cancer extension via mutated cell recruitment. However, } \\
\text { research efforts have focused on gene-manipulating MSCs. } \\
\text { Human MSCs for the delivery of osteoprotegerin genes can } \\
\text { prevent osteosarcoma }\end{array}$ & - & $\begin{array}{l}3 \times 10^{6} \text { gene- } \\
\text { modified MSCs }\end{array}$ & - & - & - & $\begin{array}{l}\text { In vivo } \\
\text { study }\end{array}$ \\
\hline \multicolumn{8}{|l|}{ Healthy } \\
\hline \multirow[t]{2}{*}{ Long bone } & & 1,500 & $52,500 \pm 2,122$ & $\begin{array}{l}150,000 \\
\pm 7,071\end{array}$ & $5 \times 10^{6}$ & $\begin{array}{l}\text { HA- } \\
\text { TCP }\end{array}$ & $\begin{array}{l}\text { Clinical } \\
\text { evidence }\end{array}$ \\
\hline & $\begin{array}{l}\text { Many clinical studies have used MSCs in the treatment of long } \\
\text { bone defects (delayed/nonunion) as successfully as trials } \\
\text { focused on oral and maxillofacial reconstruction. MSC } \\
\text { injection has been used in small defects and long critical } \\
\text { defects by clinicians and researchers using MSC-seeded } \\
\text { scaffolds/Matrigel. Scaffolds provide a 3D environment for } \\
\text { MSC growth, differentiation, and angiogenesis }\end{array}$ & & & & & & \\
\hline CF-O & & - & - & - & $\begin{array}{l}750,000 \\
\pm 353,553\end{array}$ & $\begin{array}{l}\text { BBM, } \\
\text { DBM, CS }\end{array}$ & $\begin{array}{l}\text { Clinical } \\
\text { evidence }\end{array}$ \\
\hline
\end{tabular}

MSCs, mesenchymal stem cells; CF-O, craniofacial-oral; TCP, tricalcium phosphate; CA-S, calcium sulfate; HA, hydoxyapatite; BBM, bovine bone mineral; DBM, demineralized bone matrix; CS, collagen sponge.

controls the growth condition under standardized protocols needs to be developed. In recent years, many efforts have been made and currently many clinical trials are being conducted to regenerate bone tissue using MSCs and other progenitor cells. While experimental and some clinical studies have shown beneficial effects of MSCs on bone healing, the exact mechanisms by which these cells improve bone regeneration remain unclear. Clinical applications of stem cells have been restricted by numerous factors, including: (1) ethical concerns; (2) the immunological rejection of cells from heterologous origins; (3) the limited amount of available stem cells for implantation at the injured site, requiring ex vivo expansion; (4) donor-related differences; (5) cost; (6) feasibility; (7) expertise; (8) aging; (9) translational difficulties; and (10) other factors [Hipp and Atala, 2004]. Moreover, the safety of these procedures has to be evaluated before clinical

Role of MSCs in Bone Regenerative Medicine application. In many clinical and experimental studies different procedures have been used to treat bone injuries. However, to help achieve the most practical approach, some important issues are highlighted in Table 4.

The healing rate increases in close relation with the implanted MSC concentration [Wu et al., 2007]. Concentrated MSCs can be mixed with a synthetic or natural osteoconductive matrix [Bornes et al., 2014]. As a novel strategy for MSC therapy in fracture healing, combination therapy might be used in the future. In this approach, MSCs can be implanted with a biodegradable scaffold in the fracture site and 1-2 weeks later osteoinductive genes can be injected locally at the site of implantation. Another way to achieve this goal is a reversed procedure. The various MSC delivery approaches are shown in Figure 7.

Another challenge for bone regenerative medicine at this early stage is the isolation of a specific category of

Cells Tissues Organs 2017;204:59-83

DOI: $10.1159 / 000469704$ 


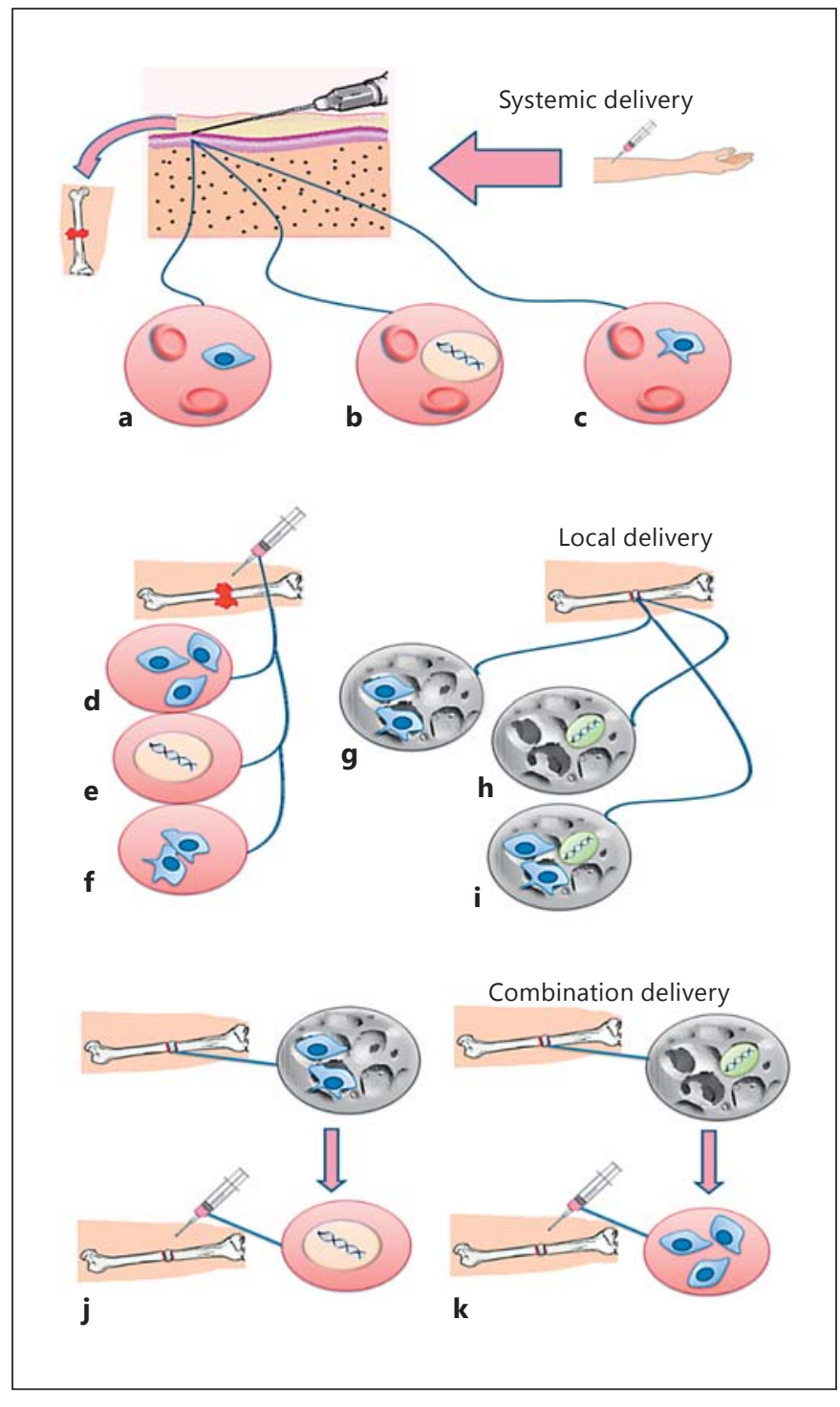

Fig. 7. MSC delivery approaches. Systemic delivery of MSCs (a), osteoinductive genes (b), and gene-modified MSCs (c) by injection into the circulatory system. Local delivery of MSCs with or without culture media (d), osteoinductive genes (e), and genemodified MSCs with or without growth factors (f) by direct injection at the fracture site. Local delivery of MSCs ( $\mathbf{g})$, osteoinductive genes (h), and MSCs with osteoinductive genes (i) by incorporation in scaffolds, which are implanted at the fracture site. Combination therapy: MSCs are implanted with scaffolds in the fracture site and osteoinductive genes are injected locally at the site of implantation 1-2 weeks later (j). By an alternative method, osteoinductive genes with scaffolds can be implanted in the fracture site and MSCs injected locally at the site of implantation 1-2 weeks later $(\mathbf{k})$. cells from donors with different individual genetic profiles due to patient variability [Nsair and MacLellan, 2011]. Moreover, different biomaterials that have been used for the scaffolding of MSCs raise technical challenges (i.e., the type of material, the special effect on bone, the effect on MSCs) [Gomez-Barrena et al., 2011]. It is important to prepare biodegradable scaffolds with osteoinductive properties; their application can provide a $3 \mathrm{D}$ environment for MSCs at the site of the defect in which they promote angiogenesis and can contribute to the healing process [Cao et al., 2014]. Finally, differentiation of the MSCs into preosteogenic cells is not fully supported by the in vivo release of osteogenic factors. Thus, by using the appropriate scaffold in an alternative approach, such problems may be solved. Furthermore, MSCs can be used together with PRP and different growth/healing promotive factors in order to improve their beneficial effects on bone healing. However, it is very difficult to conclude which elements are particularly critical and effective in stem cell therapy for bone healing because of the lack of comparative and randomized clinical studies [Evans et al., 2006]. The implementation of accurate clinical trials may help to further define and spread these therapies as a standardized cost-beneficial procedure for bone regeneration cell therapy, if their safety and efficacy is proven.

Currently, due to the lack of published clinical trials, controversies in the results, and variability in the methods, protocols and treatment strategies, it is still too soon to suggest MSC therapy for bone repair. There is still a long way to go in this regard and several issues must be scientifically addressed before it is reasonable to suggest MSCs as a therapeutic option for fracture healing.

\section{Acknowledgment}

The authors gratefully acknowledge Dr. Dimitrios Zeugolis for his scientific support and editing of the text.

\section{Disclosure Statement}

The authors declare that they have no conflicts of interest.

\section{Author Contributions}

All authors made aequal contributions in all parts of the study. A.O., A.K., A.M., and M.B.E. designed the study and participated in data collection, manuscript preparation, and revision. All authors read and approved the final manuscript.
Oryan/Kamali/Moshiri/Baghaban Eslaminejad 


\section{References}

Abdul Halim, N.S., K.S. Fakiruddin, S.A. Ali, B.H Yahaya (2014) A comparative study of nonviral gene delivery techniques to human adipose-derived mesenchymal stem cell. Int J Mol Sci 15: 15044-15060.

Abumaree, M.H., M.A. Al Jumah, B. Kalionis, D. Jawdat, A. Al Khaldi, F.M. Abomaray, A.S. Fatani, L.W. Chamley, B.A. Knawy (2013) Human placental mesenchymal stem cells (pMSCs) play a role as immune suppressive cells by shifting macrophage differentiation from inflammatory M1 to anti-inflammatory M2 macrophages. Stem Cell Rev 9: 620-641.

Achille, V., M. Mantelli, G. Arrigo, F. Novara, M.A. Avanzini, M.E. Bernardo, O. Zuffardi, G. Barosi, M. Zecca, R. Maccario (2011) Cellcycle phases and genetic profile of bone marrow-derived mesenchymal stromal cells expanded in vitro from healthy donors. J Cell Biochem 112: 1817-1821.

Amin, H.D., M.A. Brady, J.P. St-Pierre, M.M. Stevens, D.R. Overby, C.R. Ethier (2014) Stimulation of chondrogenic differentiation of adult human bone marrow-derived stromal cells by a moderate-strength static magnetic field. Tissue Eng Part A 20: 1612-1620.

Amini, A.R., C.T. Laurencin, S.P. Nukavarapu (2012) Bone tissue engineering: recent advances and challenges. Crit Rev Biomed Eng 40: 363-408.

Asami, T., M. Ishii, H. Fujii, H. Namkoong, S. Tasaka, K. Matsushita, K. Ishii, K. Yagi, H. Fujiwara, Y. Funatsu, N. Hasegawa, T. Betsuyaku (2013) Modulation of murine macrophage TLR7/8-mediated cytokine expression by mesenchymal stem cell-conditioned medium. Mediators Inflamm 2013: 264260.

Baker, N., L.B. Boyette, R.S. Tuan (2015) Characterization of bone marrow-derived mesenchymal stem cells in aging. Bone 70: 37-47.

Bernardo, M.E., N. Zaffaroni, F. Novara, A.M. Cometa, M.A. Avanzini, A. Moretta, D. Montagna, R. Maccario, R. Villa, M.G. Daidone, O. Zuffardi, F. Locatelli (2007) Human bone marrow derived mesenchymal stem cells do not undergo transformation after long-term in vitro culture and do not exhibit telomere maintenance mechanisms. Cancer Res 67: 9142-9149.

Bianco, P., P.G. Robey, P.J. Simmons (2008) Mesenchymal stem cells: revisiting history, concepts, and assays. Cell Stem Cell 2: 313-319.

Bidic, S.M., J.W. Calvert, K. Marra, P. Kumta, P. Campbell, R. Mitchell, W. Wigginton, J.O. Hollinger, L. Weiss, M.P. Mooney (2003) Rabbit calvarial wound healing by means of seeded Caprotite scaffolds. J Dent Res 82: 131-135.

Bigham-Sadegh, A., A. Oryan (2015) Basic concepts regarding fracture healing and the current options and future directions in managing bone fractures. Int Wound J 12: 238-247.

Bornes, T.D., A.B. Adesida, N.M. Jomha (2014) Mesenchymal stem cells in the treatment of traumatic articular cartilage defects: a comprehensive review. Arthritis Res Ther 16: 432.
Bose, S., M. Roy, A. Bandyopadhyay (2012) Recent advances in bone tissue engineering scaffolds. Trends Biotechnol 30: 546-554.

Cao, Z., C. Dou, S. Dong (2014) Scaffolding biomaterials for cartilage regeneration. J Nanomater 2014: 8 .

Caplan, A.I., S.P. Bruder (2001) Mesenchymal stem cells: building blocks for molecular medicine in the 21st century. Trends Mol Med 7: 259-264.

Carrion, F.A., F.E. Figueroa (2011) Mesenchymal stem cells for the treatment of systemic lupus erythematosus: is the cure for connective tissue diseases within connective tissue? Stem Cell Res Ther 2: 23.

Castelo-Branco, M.T., I.D. Soares, D.V. Lopes, F. Buongusto, C.A. Martinusso, A. do Rosario Jr, S.A. Souza, B. Gutfilen, L.M. Fonseca, C. Elia, K. Madi, A. Schanaider, M.I. Rossi, H.S. Souza (2012) Intraperitoneal but not intravenous cryopreserved mesenchymal stromal cells home to the inflamed colon and ameliorate experimental colitis. PLoS One 7: 14.

Chabner, K.T., G.B. Adams, J. Qiu, M. Moskowitz, E.S. Marsters, G.P. Topulos, D.T. Scadden (2004) Direct vascular delivery of primitive hematopoietic cells to bone marrow improves localization but not engraftment. Blood 103: 4685-4686.

Chan, B.P., T.Y. Hui, M.Y. Wong, K.H. Yip, G.C. Chan (2010) Mesenchymal stem cell-encapsulated collagen microspheres for bone tissue engineering. Tissue Eng Part C Methods 16: 225-235.

Chen, W.J., S. Jingushi, I. Aoyama, J. Anzai, G. Hirata, M. Tamura, Y. Iwamoto (2004) Effects of FGF-2 on metaphyseal fracture repair in rabbit tibiae. J Bone Miner Metab 22: $303-$ 309.

Cho, D.I., M.R. Kim, H.Y. Jeong, H.C. Jeong, M.H. Jeong, S.H. Yoon, Y.S. Kim, Y. Ahn (2014) Mesenchymal stem cells reciprocally regulate the M1/M2 balance in mouse bone marrow-derived macrophages. Exp Mol Med 46: e70.

Choi, H., R.H. Lee, N. Bazhanov, J.Y. Oh, D.J. Prockop (2011) Anti-inflammatory protein TSG-6 secreted by activated MSCs attenuates zymosan-induced mouse peritonitis by decreasing TLR2/NF- $\mathrm{KB}$ signaling in resident macrophages. Blood 118: 330-338.

Connolly, J.F. (1998) Clinical use of marrow osteoprogenitor cells to stimulate osteogenesis. Clin Orthop Relat Res 355: S257-S266.

Connolly, J.F., R. Shindell (1986) Percutaneous marrow injection for an ununited tibia. Nebr Med J 71: 105-107.

Cui, L.-l., E. Kerkelä, A. Bakreen, F. Nitzsche, A. Andrzejewska, A. Nowakowski, M. Janowski, P. Walczak, J. Boltze, B. Lukomska, J. Jolkkonen (2015) The cerebral embolism evoked by intra-arterial delivery of allogeneic bone marrow mesenchymal stem cells in rats is related to cell dose and infusion velocity. Stem Cell Res Ther 6: 11.
Das, A., D.A. Barker, T. Wang, C.M. Lau, Y. Lin, E.A. Botchwey (2014) Delivery of bioactive lipids from composite microgel-microsphere injectable scaffolds enhances stem cell recruitment and skeletal repair. PLoS One 9: e101276.

Datta, N., Q.P. Pham, U. Sharma, V.I. Sikavitsas, J.A. Jansen, A.G. Mikos (2006) In vitro generated extracellular matrix and fluid shear stress synergistically enhance 3D osteoblastic differentiation. Proc Natl Acad Sci USA 103: 24882493.

de Girolamo, L., E. Lucarelli, G. Alessandri, M.A. Avanzini, M.E. Bernardo, E. Biagi, A.T. Brini, G. D'Amico, F. Fagioli, I. Ferrero, F. Locatelli, R. Maccario, M. Marazzi, O. Parolini, A. Pessina, M.L. Torre, G; Italian Mesenchymal Stem Cell Group (2013) Mesenchymal stem/ stromal cells: a new "cells as drugs" paradigm: efficacy and critical aspects in cell therapy. Curr Pharm Des 19: 2459-2473.

De Kok, I.J., S.J. Peter, M. Archambault, C. van den Bos, S. Kadiyala, I. Aukhil, L.F. Cooper (2003) Investigation of allogeneic mesenchymal stem cell-based alveolar bone formation: preliminary findings. Clin Oral Implants Res 14: 481-489.

De Luca, A., M. Gallo, D. Aldinucci, D. Ribatti, L. Lamura, A. D’Alessio, R. De Filippi, A. Pinto, N. Normanno (2011) Role of the EGFR ligand/receptor system in the secretion of angiogenic factors in mesenchymal stem cells. J Cell Physiol 226: 2131-2138.

De Schauwer, C., G.R. Van de Walle, A. van Soom, E. Meyer (2013) Mesenchymal stem cell therapy in horses: useful beyond orthopedic injuries? Vet Q 33: 234-241.

Dennis, S.C., C.J. Berkland, L.F. Bonewald, M.S. Detamore (2015) Endochondral ossification for enhancing bone regeneration: converging native extracellular matrix biomaterials and developmental engineering in vivo. Tissue Eng Part B Rev 21: 247-266.

Ehninger, A., A. Trumpp (2011) The bone marrow stem cell niche grows up: mesenchymal stem cells and macrophages move in. J Exp Med 208: 421-428.

Elsattar, T., A. Alseedy, A. Khalil (2014) Bone marrow injection in treatment of long bone nonunion. Menoufia Med 27: 632-635.

Ennis, W.J., A. Sui, A. Bartholomew (2013) Stem cells and healing: impact on inflammation. Adv Wound Care 2: 369-378.

Eslaminejad, M.B., N. Karimi, M. Shahhoseini (2011) Enhancement of glycosaminoglycanrich matrix production in human marrowderived mesenchymal stem cell chondrogenic culture by lithium chloride and SB216763 treatment. Cell J 13: 117-126.

Eslaminejad, M.B., S. Nadri (2009) Murine mesenchymal stem cell isolated and expanded in low and high density culture system: surface antigen expression and osteogenic culture mineralization. In Vitro Cell Dev Biol Anim 45: 451-459. 
Eslaminejad, M.B., S. Nadri, R.H. Hosseini (2007) Expression of Thy 1.2 surface antigen increases significantly during the murine mesenchymal stem cells cultivation period. Dev Growth Differ 49: 351-364.

Eslaminejad, M.B., L. Rouhi, M. Arabnajafi, H. Baharvand (2009) Rat marrow-derived mesenchymal stem cells developed in a medium supplemented with the autologous versus bovine serum. Cell Biol Int 33: 607-616.

Eslaminejad, M.B., L. Taghiyar (2010) Study of the structure of canine mesenchymal stem cell osteogenic culture. Anat Histol Embryol 39: 446-455.

Evans, N.D., E. Gentleman, J.M. Polak (2006) Scaffolds for stem cells. Mater Today 9: 26-33.

Fischer, U.M., M.T. Harting, F. Jimenez, W.O. Monzon-Posadas, H. Xue, S.I. Savitz, G.A. Laine, C.S. Cox Jr. (2009) Pulmonary passage is a major obstacle for intravenous stem cell delivery: the pulmonary first-pass effect. Stem Cells Dev 18: 683-692.

Formiga, F.R., B. Pelacho, E. Garbayo, G. Abizanda, J.J. Gavira, T. Simon-Yarza, M. Mazo, E. Tamayo, C. Jauquicoa, C. Ortiz-de-Solorzano, F. Prosper, M.J. Blanco-Prieto (2010) Sustained release of VEGF through PLGA microparticles improves vasculogenesis and tissue remodeling in an acute myocardial ischemia-reperfusion model. J Control Release 147: 30-37.

Friedenstein, A.J., R.K. Chailakhjan, K.S. Lalykina (1970) The development of fibroblast colonies in monolayer cultures of guinea-pig bone marrow and spleen cells. Cell Tissue Kinet 3: 393-403.

Frohlich, M., W.L. Grayson, L.Q. Wan, D. Marolt, M. Drobnic, G. Vunjak-Novakovic (2008) Tissue engineered bone grafts: biological requirements, tissue culture and clinical relevance. Curr Stem Cell Res Ther 3: 254-264.

Gamradt, S.C., N. Abe, M.E. Bahamonde, Y.P. Lee, S.D. Nelson, K.M. Lyons, J.R. Lieberman (2006) Tracking expression of virally mediated BMP-2 in gene therapy for bone repair. Clin Orthop Relat Res 450: 238-245.

Gentile, P., A. Orlandi, M.G. Scioli, C. Di Pasquali, I. Bocchini, V. Cervelli (2012) Concise review: adipose-derived stromal vascular fraction cells and platelet-rich plasma: basic and clinical implications for tissue engineering therapies in regenerative surgery. Stem Cells Transl Med 1: 230-236.

Gimbel, M., R.K. Ashley, M. Sisodia, J.S. Gabbay, K.L. Wasson, J. Heller, L. Wilson, H.K. Kawamoto, J.P. Bradley (2007) Repair of alveolar cleft defects: reduced morbidity with bone marrow stem cells in a resorbable matrix. J Craniofac Surg 18: 895-901.

Giuliani, N., G. Lisignoli, M. Magnani, C. Racano, M. Bolzoni, B. Dalla Palma, A. Spolzino, C. Manferdini, C. Abati, D. Toscani, A. Facchini, F. Aversa (2013) New insights into osteogenic and chondrogenic differentiation of human bone marrow mesenchymal stem cells and their potential clinical applications for bone regeneration in pediatric orthopaedics. Stem Cells Int 2013: 312501.
Glenn, J.D., K.A. Whartenby (2014) Mesenchymal stem cells: emerging mechanisms of immunomodulation and therapy. World J Stem Cells 6: 526-539.

Gomez-Barrena, E., P. Rosset, I. Muller, R. Giordano, C. Bunu, P. Layrolle, Y.T. Konttinen, F.P. Luyten (2011) Bone regeneration: stem cell therapies and clinical studies in orthopaedics and traumatology. J Cell Mol Med 15: 1266-1286

Gordon, J.A., M.Q. Hassan, M. Koss, M. Montecino, L. Selleri, A.J. van Wijnen, J.L. Stein, G.S. Stein, J.B. Lian (2011) Epigenetic regulation of early osteogenesis and mineralized tissue formation by a HOXA10-PBX1-associated complex. Cells Tissues Organs 194: 146-150.

Granero-Moltó, F., J.A. Weis, M.I. Miga, B. Landis, T.J. Myers, L. O’Rear, L. Longobardi, E.D. Jansen, D.P. Mortlock, A. Spagnoli (2009) Regenerative effects of transplanted mesenchymal stem cells in fracture healing. Stem Cells 27: 1887-1898.

Grayson, W.L., B.A. Bunnell, E. Martin, T. Frazier, B.P. Hung, J.M. Gimble (2015) Stromal cells and stem cells in clinical bone regeneration. Nat Rev Endocrinol 11: 140-150.

Grellier, M., L. Bordenave, J. Amedee (2009) Cellto-cell communication between osteogenic and endothelial lineages: implications for tissue engineering. Trends Biotechnol 27: 562-571.

Guo, X., H. Park, G. Liu, W. Liu, Y. Cao, Y. Tabata, F.K. Kasper, A.G. Mikos (2009) In vitro generation of an osteochondral construct using injectable hydrogel composites encapsulating rabbit marrow mesenchymal stem cells. Biomaterials 30: 2741-2752.

Hauzeur, J.P., V. Gangii (2010) Phases 1-3 clinical trials using adult stem cells in osteonecrosis and nonunion fractures. Stem Cells Int 26: 410170.

Hayashi, O., Y. Katsube, M. Hirose, H. Ohgushi, H. Ito (2008) Comparison of osteogenic ability of rat mesenchymal stem cells from bone marrow, periosteum, and adipose tissue. Calcif Tissue Int 82: 238-247.

He, X., R. Dziak, X. Yuan, K. Mao, R. Genco, M. Swihart, D. Sarkar, C. Li, C. Wang, L. Lu, S. Andreadis, S. Yang (2013) BMP2 genetically engineered MSCs and EPCs promote vascularized bone regeneration in rat critical-sized calvarial bone defects. PLoS One 8: e60473.

Healey, J.H., P.A. Zimmerman, J.M. McDonnell, J.M. Lane (1990) Percutaneous bone marrow grafting of delayed union and nonunion in cancer patients. Clin Orthop Relat Res 256: 280-285.

Hermund, N.U., A. Stavropoulos, O. Donatsky, H. Nielsen, C. Clausen, J. Reibel, B. Pakkenberg, P. Holmstrup (2012) Reimplantation of cultivated human bone cells from the posterior maxilla for sinus floor augmentation: histological results from a randomized controlled clinical trial. Clin Oral Implants Res 23: 1031-1037.

Hernigou, P., F. Beaujean (2002) Treatment of osteonecrosis with autologous bone marrow grafting. Clin Orthop Relat Res 405: 14-23.
Hernigou, P., G. Mathieu, A. Poignard, O. Manicom, F. Beaujean, H. Rouard (2006) Percutaneous autologous bone-marrow grafting for nonunions: surgical technique. J Bone Joint Surg Am 88(suppl 1): 322-327.

Hipp, J., A. Atala (2004) Tissue engineering, stem cells, cloning, and parthenogenesis: new paradigms for therapy. J Exp Clin Assist Reprod 1: 3 .

Horwitz, E.M., P.L. Gordon, W.K. Koo, J.C. Marx, M.D. Neel, R.Y. McNall, L. Muul, T. Hofmann (2002) Isolated allogeneic bone marrow-derived mesenchymal cells engraft and stimulate growth in children with osteogenesis imperfecta: implications for cell therapy of bone. Proc Natl Acad Sci USA 99: 8932-8937.

Horwitz, E.M., D.J. Prockop, L.A. Fitzpatrick, W.W. Koo, P.L. Gordon, M. Neel, M. Sussman, P. Orchard, J.C. Marx, R.E. Pyeritz, M.K. Brenner (1999) Transplantability and therapeutic effects of bone marrow-derived mesenchymal cells in children with osteogenesis imperfecta. Nat Med 5: 309-313.

Horwitz, E.M., D.J. Prockop, P.L. Gordon, W.W. Koo, L.A. Fitzpatrick, M.D. Neel, M.E. McCarville, P.J. Orchard, R.E. Pyeritz, M.K. Brenner (2001) Clinical responses to bone marrow transplantation in children with severe osteogenesis imperfecta. Blood 97: 12271231.

Houlden, H., P. Charlton, D. Singh (2007) Neurology and orthopaedics. J Neurol Neurosurg Psychiatry 78: 224-232.

Huang, S., L. Xu, Y. Zhang, Y. Sun, G. Li (2015) Systemic and local administration of allogeneic bone marrow derived mesenchymal stem cells promotes fracture healing in rats. Cell Transplant 24: 2643-2655.

Hudson, J.W., J.G. Anderson, R.M. Russell Jr, N. Anderson, K. Chambers (1995) Use of pedicled fat pad graft as an adjunct in the reconstruction of palatal cleft defects. Oral Surg Oral Med Oral Pathol Oral Radiol Endod 80: 24-27.

Izadpanah, R., B.A. Bunnell (2008) Gene delivery to mesenchymal stem cells. Methods Mol Biol 449: 153-167.

Jacobs, S.A., V.D. Roobrouck, C.M. Verfaillie, S.W. van Gool (2013) Immunological characteristics of human mesenchymal stem cells and multipotent adult progenitor cells. Immunol Cell Biol 91: 32-39.

Jafarian, M., M.B. Eslaminejad, A. Khojasteh, F. Mashhadi Abbas, M.M. Dehghan, R. Hassanizadeh, B. Houshmand (2008) Marrow-derived mesenchymal stem cells-directed bone regeneration in the dog mandible: a comparison between biphasic calcium phosphate and natural bone mineral. Oral Surg Oral Med Oral Pathol Oral Radiol Endod 105: e14-e24.

Janowski, M., A. Lyczek, C. Engels, J. Xu, B. Lukomska, J.W. Bulte, P. Walczak (2013) Cell size and velocity of injection are major determinants of the safety of intracarotid stem cell transplantation. J Cereb Blood Flow Metab 33: 921-927. 
Jones, E.A., A. English, K. Henshaw, S.E. Kinsey, A.F. Markham, P. Emery, D. McGonagle (2004) Enumeration and phenotypic characterization of synovial fluid multipotential mesenchymal progenitor cells in inflammatory and degenerative arthritis. Arthritis Rheum 50: 817-827.

Jurgens, W.J., R.J. Kroeze, B. Zandieh-Doulabi, A. van Dijk, G.A. Renders, T.H. Smit, F.J. van Milligen, M.J. Ritt, M.N. Helder (2013) Onestep surgical procedure for the treatment of osteochondral defects with adipose-derived stem cells in a caprine knee defect: a pilot study. Biores Open Access 2: 315-325.

Kadiyala, S., R.G. Young, M.A. Thiede, S.P. Bruder (1997) Culture expanded canine mesenchymal stem cells possess osteochondrogenic potential in vivo and in vitro. Cell Transplant 6: 125-134.

Kaigler, D., G. Pagni, C.H. Park, T.M. Braun, L.A. Holman, E. Yi, S.A. Tarle, R.L. Bartel, W.V. Giannobile (2013) Stem cell therapy for craniofacial bone regeneration: a randomized, controlled feasibility trial. Cell Transplant 22: 767-777.

Kean, T.J., P. Lin, A.I. Caplan, J.E. Dennis (2013) MSCs: delivery routes and engraftment, celltargeting strategies, and immune modulation. Stem Cells Int 2013: 732742.

Kim, J., I.S. Kim, T.H. Cho, H.C. Kim, S.J. Yoon, J. Choi, Y. Park, K. Sun, S.J. Hwang (2010) In vivo evaluation of MMP sensitive high-molecular weight HA-based hydrogels for bone tissue engineering. J Biomed Mater Res A 95: 673-681.

Kim, J., I.S. Kim, T.H. Cho, K.B. Lee, S.J. Hwang, G. Tae, I. Noh, S.H. Lee, Y. Park, K. Sun (2007) Bone regeneration using hyaluronic acid-based hydrogel with bone morphogenic protein-2 and human mesenchymal stem cells. Biomaterials 28: 1830-1837.

Kim, S.-H., Y.-S. Kim, S.-Y. Lee, K.-H. Kim, Y.-M. Lee, W.-K. Kim, Y.-K. Lee (2011) Gene expression profile in mesenchymal stem cells derived from dental tissues and bone marrow. J Periodontal Implant Sci 41: 192-200.

Kim, S.J., Y.W. Shin, K.H. Yang, S.B. Kim, M.J. Yoo, S.K. Han, S.A. Im, Y.D. Won, Y.B. Sung, T.S. Jeon, C.H. Chang, J.D. Jang, S.B. Lee, H.C. Kim, S.Y. Lee (2009) A multi-center, randomized, clinical study to compare the effect and safety of autologous cultured osteoblast (Ossron) injection to treat fractures. BMC Musculoskelet Disord 10: 20.

Kitaori, T., H. Ito, E.M. Schwarz, R. Tsutsumi, H. Yoshitomi, S. Oishi, M. Nakano, N. Fujii, T. Nagasawa, T. Nakamura (2009) Stromal cellderived factor 1/CXCR4 signaling is critical for the recruitment of mesenchymal stem cells to the fracture site during skeletal repair in a mouse model. Arthritis Rheum 60: 813-823.

Kovach, T.K., A.S. Dighe, P.I. Lobo, Q. Cui (2015) Interactions between MSCs and immune cells: implications for bone healing. J Immunol Res 2015: 17.

Krebsbach, P.H., M.H. Mankani, K. Satomura, S.A. Kuznetsov, P.G. Robey (1998) Repair of craniotomy defects using bone marrow stromal cells. Transplantation 66: 1272-1278.

Le Blanc, K., C. Gotherstrom, O. Ringden, M. Hassan, R. McMahon, E. Horwitz, G. Anneren, O. Axelsson, J. Nunn, U. Ewald, S. Norden-Lindeberg, M. Jansson, A. Dalton, E. Astrom, M. Westgren (2005) Fetal mesenchymal stem-cell engraftment in bone after in utero transplantation in a patient with severe osteogenesis imperfecta. Transplantation 79: 1607-1614.

Lee, G.S., J.H. Park, U.S. Shin, H.W. Kim (2011) Direct deposited porous scaffolds of calcium phosphate cement with alginate for drug delivery and bone tissue engineering. Acta Biomater 7: 3178-3186.

Lee, J.H., N.G. Rim, H.S. Jung, H. Shin (2010) Control of osteogenic differentiation and mineralization of human mesenchymal stem cells on composite nanofibers containing poly[lactic-co-(glycolic acid)] and hydroxyapatite. Macromol Biosci 10: 173-182.

Lee, O.K., T.K. Kuo, W.M. Chen, K.D. Lee, S.L. Hsieh, T.H. Chen (2004) Isolation of multipotent mesenchymal stem cells from umbilical cord blood. Blood 103: 1669-1675.

Lee, R.H., A.A. Pulin, M.J. Seo, D.J. Kota, J. Ylostalo, B.L. Larson, L. Semprun-Prieto, P. Delafontaine, D.J. Prockop (2009) Intravenous hMSCs improve myocardial infarction in mice because cells embolized in lung are activated to secrete the anti-inflammatory protein TSG-6. Cell Stem Cell 5: 54-63.

Levi, B., A.W. James, E.R. Nelson, S. Li, M. Peng, G.W. Commons, M. Lee, B. Wu, M.T. Longaker (2010) Human adipose-derived stromal cells stimulate autogenous skeletal repair via paracrine hedgehog signaling with calvarial osteoblasts. Stem Cells Dev 20: 243-257.

Levi, B., M.T. Longaker (2011) Adipose derived stromal cells for skeletal regenerative medicine. Stem Cells 29: 576-582.

Li, F., N. Whyte, C. Niyibizi (2012) Differentiating multipotent mesenchymal stromal cells generate factors that exert paracrine activities on exogenous MSCs: implications for paracrine activities in bone regeneration. Biochem Biophys Res Commun 426: 475-479.

Li, H., K. Dai, T. Tang, X. Zhang, M. Yan, J. Lou (2007) Bone regeneration by implantation of adipose-derived stromal cells expressing BMP-2. Biochem Biophys Res Commun 356: 836-842.

Liao, J., X. Guo, D. Nelson, F.K. Kasper, A.G. Mikos (2010) Modulation of osteogenic properties of biodegradable polymer/extracellular matrix scaffolds generated with a flow perfusion bioreactor. Acta Biomater 6: 2386-2393.

Liebergall, M., J. Schroeder, R. Mosheiff, Z. Gazit, Z. Yoram, L. Rasooly, A. Daskal, A. Khoury, Y. Weil, S. Beyth (2013) Stem cell-based therapy for prevention of delayed fracture union: a randomized and prospective preliminary study. Mol Ther 21: 1631-1638.

Lotfy, A., M. Salama, F. Zahran, E. Jones, A. Badawy, M. Sobh (2014) Characterization of mesenchymal stem cells derived from rat bone marrow and adipose tissue: a comparative study. Int J Stem Cells 7: 135-142.

Luo, Y., M.S. Shoichet (2004) Light-activated immobilization of biomolecules to agarose hydrogels for controlled cellular response. Biomacromolecules 5: 2315-2323.

Mallela, J., S. Ravi, F. Jean Louis, B. Mulaney, M. Cheung, U. Sree Garapati, V. Chinnasamy, C. Wang, S. Nagaraj, S.S. Mohapatra, S. Mohapatra (2013) Natriuretic peptide receptor A signaling regulates stem cell recruitment and angiogenesis: a model to study linkage between inflammation and tumorigenesis. Stem Cells 31: 1321-1329.

Mallick, K.K., S.C. Cox (2013) Biomaterial scaffolds for tissue engineering. Front Biosci 5: 341-360.

Mangano, F., F. Luongo, J.A. Shibli, S. Anil, C. Mangano (2014) Maxillary overdentures supported by four splinted direct metal laser sintering implants: a 3-year prospective clinical study. Int J Dent 2014: 9.

Manieri, N.A., M.R. Mack, M.D. Himmelrich, D.L. Worthley, E.M. Hanson, L. Eckmann, T.C. Wang, T.S. Stappenbeck (2015) Mucosally transplanted mesenchymal stem cells stimulate intestinal healing by promoting angiogenesis. J Clin Invest 125: 3606-3618.

Mankani, M.H., S.A. Kuznetsov, R.M. Wolfe, G.W. Marshall, P.G. Robey (2006) In vivo bone formation by human bone marrow stromal cells: reconstruction of the mouse calvarium and mandible. Stem Cells 24: 2140-2149.

Marion, N.W., J.J. Mao (2006) Mesenchymal stem cells and tissue engineering. Methods Enzymol 420: 339-361.

Marrelli, M., G. Falisi, A. Apicella, D. Apicella, M. Amantea, A. Cielo, L. Bonanome, F. Palmieri, L. Santacroce, S. Giannini, E. Di Fabrizio, C. Rastelli, M. Gargari, G. Cuda, F. Paduano, M. Tatullo (2015a) Behaviour of dental pulp stem cells on different types of innovative mesoporous and nanoporous silicon scaffolds with different functionalizations of the surfaces. J Biol Regul Homeost Agents 29: 991-997.

Marrelli, M., F. Paduano, M. Tatullo (2015b) Human periapical cyst-mesenchymal stem cells differentiate into neuronal cells. J Dent Res 94: 843-852.

Marrelli, M., M. Tatullo (2013) Influence of PRF in the healing of bone and gingival tissues: clinical and histological evaluations. Eur Rev Med Pharmacol Sci 17: 1958-1962.

Mathieu, P.S., E.G. Loboa (2012) Cytoskeletal and focal adhesion influences on mesenchymal stem cell shape, mechanical properties, and differentiation down osteogenic, adipogenic, and chondrogenic pathways. Tissue Eng B Rev 18: 436-444.

Mehta, M., K. Schmidt-Bleek, G.N. Duda, D.J. Mooney (2012) Biomaterial delivery of morphogens to mimic the natural healing cascade in bone. Adv Drug Deliv Rev 64: 1257-1276.

Meier, R.P., Y.D. Muller, P. Morel, C. GonelleGispert, L.H. Buhler (2013) Transplantation of mesenchymal stem cells for the treatment of liver diseases, is there enough evidence? Stem Cell Res 11: 1348-1364.
Role of MSCs in Bone Regenerative Medicine
Cells Tissues Organs 2017;204:59-83

DOI: $10.1159 / 000469704$ 
Melek, L.N. (2015) Tissue engineering in oral and maxillofacial reconstruction. Tanta Dent J 12 : 211-223.

Monteiro, D.R., E.V. Silva, E.P. Pellizzer, O.M. Filho, M.C. Goiato (2015) Posterior partially edentulous jaws, planning a rehabilitation with dental implants. World J Clin Cases 3: 65-76.

Moreau, J.L., H.H. Xu (2009) Mesenchymal stem cell proliferation and differentiation on an injectable calcium phosphate-chitosan composite scaffold. Biomaterials 30: 2675-2682.

Moshiri, A., A. Oryan (2013) Role of platelet-rich plasma in soft and hard connective tissue healing: an evidence-based review from basic to clinical application. Hard Tissue 2: 6 .

Moshiri, A., A. Oryan, A. Meimandi-Parizi (2015a) Synthesis, development, characterization and effectiveness of bovine pure platelet gel-collagen-polydioxanone bioactive graft on tendon healing. J Cell Mol Med 19: 1308-1332.

Moshiri, A., M. Shahrezaee, B. Shekarchi, A. Oryan, K. Azma (2015b) Three-dimensional porous Gelapin-Simvastatin scaffolds promoted bone defect healing in rabbits. Calcif Tissue Int 96: 552-564.

Murphy, C.M., M.G. Haugh, F.J. O’Brien (2010) The effect of mean pore size on cell attachment, proliferation and migration in collagen-glycosaminoglycan scaffolds for bone tissue engineering. Biomaterials 31: 461-466.

Murphy, M.B., K. Moncivais, A.I. Caplan (2013) Mesenchymal stem cells: environmentally responsive therapeutics for regenerative medicine. Exp Mol Med 45: e54.

Murrell, W.D., A.W. Anz, H. Badsha, W.F. Bennett, R.E. Boykin, A.I. Caplan (2015) Regenerative treatments to enhance orthopedic surgical outcome. Pm R 7(suppl 4): S41-S52.

Nanes, M.S. (2003) Tumor necrosis factor- $\alpha$ : molecular and cellular mechanisms in skeletal pathology. Gene 321: 1-15.

Nsair, A., W.R. MacLellan (2011) Induced pluripotent stem cells for regenerative cardiovascular therapies and biomedical discovery. Adv Drug Deliv Rev 63: 324-330.

Olmsted-Davis, E., F.H. Gannon, M. Ozen, M.M. Ittmann, Z. Gugala, J.A. Hipp, K.M. Moran, C.M. Fouletier-Dilling, S. Schumara-Martin, R.W. Lindsey, M.H. Heggeness, M.K. Brenner, A.R. Davis (2007) Hypoxic adipocytes pattern early heterotopic bone formation. Am J Pathol 170: 620-632.

Oryan, A., S. Alidadi, A. Moshiri, A. BighamSadegh (2014a) Bone morphogenetic proteins: a powerful osteoinductive compound with non-negligible side effects and limitations. Biofactors 40: 459-481.

Oryan, A., S. Alidadi, A. Moshiri, N. Maffulli (2014b) Bone regenerative medicine: classic options, novel strategies, and future directions. J Orthop Surg Res 9: 9-18.

Oryan, A., A. Kamali, A. Moshiri (2015) Potential mechanisms and applications of statins on osteogenesis: current modalities, conflicts and future directions. J Control Release 215: 12-24.
Oryan, A., A. Moshiri (2013) Tissue engineering: alternative option in managing large and massive tissue deficits. Trop Med Surg 1: e101.

Otsuru, S., K. Tamai, T. Yamazaki, H. Yoshikawa, Y. Kaneda (2007) Bone marrow-derived osteoblast progenitor cells in circulating blood contribute to ectopic bone formation in mice. Biochem Biophys Res Commun 354: 453458.

Pak, J., J.H. Lee, S.H. Lee (2014) Regenerative repair of damaged meniscus with autologous adipose tissue-derived stem cells. Biomed Res Int 436029: 30.

Papandreou, I., R.A. Cairns, L. Fontana, A.L. Lim, N.C. Denko (2006) HIF-1 mediates adaptation to hypoxia by actively downregulating mitochondrial oxygen consumption. Cell Metab 3: 187-197.

Park, S.H., A. Tofighi, X. Wang, M. Strunk, T. Ricketts, J. Chang, D.L. Kaplan (2011) Calcium phosphate combination biomaterials as human mesenchymal stem cell delivery vehicles for bone repair. J Biomed Mater Res B Appl Biomater 97: 235-244.

Pelegrine, A.A., C.E. da Costa, M.E. Correa, J.F. Marques Jr. (2010) Clinical and histomorphometric evaluation of extraction sockets treated with an autologous bone marrow graft. Clin Oral Implants Res 21: 535-542.

Peng, F., H. Wu, Y. Zheng, X. Xu, J. Yu (2012) The effect of noncoherent red light irradiation on proliferation and osteogenic differentiation of bone marrow mesenchymal stem cells. Lasers Med Sci 27: 645-653.

Pham, Q.P., F.K. Kasper, A.S. Mistry, U. Sharma, A.W. Yasko, J.A. Jansen, A.G. Mikos (2009) Analysis of the osteoinductive capacity and angiogenicity of an in vitro generated extracellular matrix. J Biomed Mater Res A 88: 295-303.

Pitchford, S.C., R.C. Furze, C.P. Jones, A.M. Wengner, S.M. Rankin (2009) Differential mobilization of subsets of progenitor cells from the bone marrow. Cell Stem Cell 4: 6272.

Pittet, M.J., M. Nahrendorf, F.K. Swirski (2014) The journey from stem cell to macrophage. Ann NY Acad Sci 1319: 1-18.

Poser, L., R. Matthys, P. Schawalder, S. Pearce, M. Alini, S. Zeiter (2014) A standardized critical size defect model in normal and osteoporotic rats to evaluate bone tissue engineered constructs. Biomed Res Int 2014: 11348635.

Qin, X., R.M. Raj, X.F. Liao, W. Shi, B. Ma, S.Q. Gong, W.M. Chen, B. Zhou (2014a) Using rigidly fixed autogenous tooth graft to repair bone defect: an animal model. Dent Traumatol 30: 380-384.

Qin, Y., J. Guan, C. Zhang (2014b) Mesenchymal stem cells: mechanisms and role in bone regeneration. Postgrad Med J 90: 643-647.

Radice, M., P. Brun, R. Cortivo, R. Scapinelli, C. Battaliard, G. Abatangelo (2000) Hyaluronan-based biopolymers as delivery vehicles for bone-marrow-derived mesenchymal progenitors. J Biomed Mater Res 50: 101-109.
Rauh, J., F. Milan, K.P. Gunther, M. Stiehler (2011) Bioreactor systems for bone tissue engineering. Tissue Eng B Rev 17: 263-280.

Raynaud, C.M., A. Rafii (2013) The necessity of a systematic approach for the use of MSCs in the clinical setting. Stem Cells Int 2013: 892340.

Reiser, J., X.Y. Zhang, C.S. Hemenway, D. Mondal, L. Pradhan, V.F. La Russa (2005) Potential of mesenchymal stem cells in gene therapy approaches for inherited and acquired diseases. Expert Opin Biol Ther 5: 1571-1584.

Rickert, D., S. Sauerbier, H. Nagursky, D. Menne, A. Vissink, G.M. Raghoebar (2011) Maxillary sinus floor elevation with bovine bone mineral combined with either autogenous bone or autogenous stem cells: a prospective randomized clinical trial. Clin Oral Implants Res 22: 251-258.

Robey, P.G. (2011) Cell sources for bone regeneration: the good, the bad, and the ugly (but promising). Tissue Eng B Rev 17: 423-430.

Roddy, G.W., J.Y. Oh, R.H. Lee, T.J. Bartosh, J. Ylostalo, K. Coble, R.H. Rosa Jr, D.J. Prockop (2011) Action at a distance: systemically administered adult stem/progenitor cells (MSCs) reduce inflammatory damage to the cornea without engraftment and primarily by secretion of TNF- $\alpha$ stimulated gene/protein 6. Stem Cells 29: 1572-1579.

Rokn, A., A.R. Ghahroudi, S. Hemati, A. Soolari (2011) Comparison of peri-implant bone loss and survival of maxillary intrasinus and extrasinus implants after 2 years. J Dent $8: 130-137$.

Roy, S., J. Driggs, H. Elgharably, S. Biswas, M. Findley, S. Khanna, U. Gnyawali, V.K. Bergdall, C.K. Sen (2011) Platelet-rich fibrin matrix improves wound angiogenesis via inducing endothelial cell proliferation. Wound Repair Regen 19: 753-766.

Santos, J.L., D. Pandita, J. Rodrigues, A.P. Pego, P.L. Granja, H. Tomas (2011) Non-viral gene delivery to mesenchymal stem cells: methods, strategies and application in bone tissue engineering and regeneration. Curr Gene Ther 11: 46-57.

Sarkar, S.K., B.T. Lee (2015) Hard tissue regeneration using bone substitutes: an update on innovations in materials. Korean J Intern Med 30: 279-293.

Sauerbier, S., D. Rickert, R. Gutwald, H. Nagursky, T. Oshima, S.P. Xavier, J. Christmann, P. Kurz, D. Menne, A. Vissink, G. Raghoebar, R. Schmelzeisen, W. Wagner, F.P. Koch (2011) Bone marrow concentrate and bovine bone mineral for sinus floor augmentation: a controlled, randomized, single-blinded clinical and histological trial - per-protocol analysis. Tissue Eng A 17: 2187-2197.

Sauerbier, S., A. Stricker, J. Kuschnierz, F. Buhler, T. Oshima, S.P. Xavier, R. Schmelzeisen, R. Gutwald (2010) In vivo comparison of hard tissue regeneration with human mesenchymal stem cells processed with either the FICOLL method or the BMAC method. Tissue Engineering C Methods 16: 215-223. 
Schmidt-Bleek, K., H. Schell, J. Lienau, N. Schulz, P. Hoff, M. Pfaff, G. Schmidt, C. Martin, C. Perka, F. Buttgereit, H.D. Volk, G. Duda (2014) Initial immune reaction and angiogenesis in bone healing. J Tissue Eng Regen Med 8: 120-130.

Seamon, J., X. Wang, F. Cui, T. Keller, A.S. Dighe, G. Balian, Q. Cui (2013) Adenoviral delivery of the VEGF and BMP- 6 genes to rat mesenchymal stem cells potentiates osteogenesis. Bone Marrow Res 2013: 737580.

Shao, J., W. Zhang, T. Yang (2015) Using mesenchymal stem cells as a therapy for bone regeneration and repairing. Biol Res 48: 62.

Simmons, C.A., E. Alsberg, S. Hsiong, W.J. Kim, D.J. Mooney (2004) Dual growth factor delivery and controlled scaffold degradation enhance in vivo bone formation by transplanted bone marrow stromal cells. Bone 35: 562-569.

Smadja, D.M., C. d'Audigier, C.L. Guerin, L. Mauge, B. Dizier, J.S. Silvestre, L. Dal Cortivo, P. Gaussem, J. Emmerich (2012) Angiogenic potential of BM MSCs derived from patients with critical leg ischemia. Bone Marrow Transplant 47: 997-1000.

Sorrell, J.M., M.A. Baber, A.I. Caplan (2009) Influence of adult mesenchymal stem cells on in vitro vascular formation. Tissue Eng A 15: 1751-1761.

Stroncek, J.D., W.M. Reichert (2008) Overview of wound healing in different tissue types; in Reichert WM (ed): Indwelling Neural Implants: Strategies for Contending with the in vivo Environment. Boca Raton, CRC Press.

Sun, H., Z. Qu, Y. Guo, G. Zang, B. Yang (2007) In vitro and in vivo effects of rat kidney vascular endothelial cells on osteogenesis of rat bone marrow mesenchymal stem cells growing on polylactide-glycoli acid (PLGA) scaffolds. Biomed Eng Online 6: 41.

Tao, J., Y. Sun, Q.G. Wang, C.W. Liu (2009) Induced endothelial cells enhance osteogenesis and vascularization of mesenchymal stem cells. Cells Tissues Organs 190: 185-193.

Tatullo, M., G. Falisi, M. Amantea, C. Rastelli, F. Paduano, M. Marrelli (2015a) Dental pulp stem cells and human periapical cysts mesenchymal stem cells in bone tissue regeneration: comparison of basal and osteogenic differentiated gene expression of a newly discovered mesenchymal stem cell lineage. J Biol Regul Homeost Agents 29: 713-718.

Tatullo, M., M. Marrelli, G. Falisi, C. Rastelli, F. Palmieri, M. Gargari, B. Zavan, F. Paduano, V. Benagiano (2016) Mechanical influence of tissue culture plates and extracellular matrix on mesenchymal stem cell behavior: a topical review. Int J Immunopathol Pharmacol 29: 3-8.

Tatullo, M., M. Marrelli, F. Paduano (2015b) The regenerative medicine in oral and maxillofacial surgery: the most important innovations in the clinical application of mesenchymal stem cells. Int J Med Sci 12: 72-77.
Tatullo, M., M. Marrelli, K.M. Shakesheff, L.J. White (2015c) Dental pulp stem cells: function, isolation and applications in regenerative medicine. J Tissue Eng Regen Med 9: 1205-1216.

Tavakolinejad, S., A. Ebrahimzadeh Bidskan, H. Ashraf, D. Hamidi Alamdari (2014) A glance at methods for cleft palate repair. Iran Red Crescent Med J 16: e15393.

Terella, A., P. Mariner, N. Brown, K. Anseth, S.O. Streubel (2010) Repair of a calvarial defect with biofactor and stem cell-embedded polyethylene glycol scaffold. Arch Facial Plastic Surg 12: 166-171.

Thibault, R.A., L. Scott Baggett, A.G. Mikos, F.K. Kasper (2010) Osteogenic differentiation of mesenchymal stem cells on pregenerated extracellular matrix scaffolds in the absence of osteogenic cell culture supplements. Tissue Eng A 16: 431-440.

Toupadakis, C.A., A. Wong, D.C. Genetos, D.J. Chung, D. Murugesh, M.J. Anderson, G.G. Loots, B.A. Christiansen, A.S. Kapatkin, C.E. Yellowley (2012) Long-term administration of AMD3100, an antagonist of SDF-1/CXCR4 signaling, alters fracture repair. J Orthop Res 30: $1853-1859$.

Trautmann, F., M. Cojoc, I. Kurth, N. Melin, L.C. Bouchez, A. Dubrovska, C. Peitzsch (2014) CXCR4 as biomarker for radioresistant cancer stem cells. Int J Radiat Biol 90: 687-699.

Umebayashi, M., Y. Sumita, Y. Kawai, S. Watanabe, I. Asahina (2015) Gene-activated matrix comprised of atelocollagen and plasmid DNA encoding BMP4 or Runx 2 promotes rat cranial bone augmentation. Biores Open Access 4: 164-174.

Wang, Z., H. Song, H. Deng, J. Chen, L. Zhang, Y. $\mathrm{Li}$ (2009) Causes and treatment of long bone fracture nonunion after allogeneic bone grafting surgery (in Chinese). Zhongguo Xiu Fu Chong Jian Wai Ke Za Zhi 23: 534-537.

Waterman, R.S., S.L. Tomchuck, S.L. Henkle, A.M. Betancourt (2010) A new mesenchymal stem cell (MSC) paradigm: polarization into a pro-inflammatory MSC1 or an Immunosuppressive MSC2 phenotype. PLoS One 5: e10088.

Williams, D.F. (2008) On the mechanisms of biocompatibility. Biomaterials 29: 2941-2953.

Wu, C., Y. Zhou, W. Fan, P. Han, J. Chang, J. Yuen, M. Zhang, Y. Xiao (2012) Hypoxia-mimicking mesoporous bioactive glass scaffolds with controllable cobalt ion release for bone tissue engineering. Biomaterials 33: 2076-2085.

Wu, Y., L. Chen, P.G. Scott, E.E. Tredget (2007) Mesenchymal stem cells enhance wound healing through differentiation and angiogenesis. Stem Cells 25: 2648-2659.

Wyse, R.D., G.L. Dunbar, J. Rossignol (2014) Use of genetically modified mesenchymal stem cells to treat neurodegenerative diseases. Int J Mol Sci 15: 1719-1745.

Xue, Y., Z. Xing, S. Hellem, K. Arvidson, K. Mustafa (2009) Endothelial cells influence the osteogenic potential of bone marrow stromal cells. Biomed Eng Online 8: 34.
Yang, C., H. Frei, F.M. Rossi, H.M. Burt (2009) The differential in vitro and in vivo responses of bone marrow stromal cells on novel porous gelatin-alginate scaffolds. J Tissue Eng Regen Med 3: 601-614.

Yeatts, A.B., J.P. Fisher (2011) Bone tissue engineering bioreactors: dynamic culture and the influence of shear stress. Bone 48: 171-181.

Yellowley, C. (2013) CXCL12/CXCR4 signaling and other recruitment and homing pathways in fracture repair. Bonekey Rep 2: 34.

Yim, E.K., E.M. Darling, K. Kulangara, F. Guilak, K.W. Leong (2010) Nanotopography-induced changes in focal adhesions, cytoskeletal organization, and mechanical properties of human mesenchymal stem cells. Biomaterials 31: 1299-1306.

Young, H.E., L. Hyer, A.C. Black, J.S. Robinson (2014) Adult stem cells: from bench-top to bedside; in Liu, Q. (ed): Tissue Regeneration: Where Nano-Structure Meets Biology. Singapore, World Scientific, pp 1-59.

Zeng, Y., X. Qu, H. Li, S. Huang, S. Wang, Q. Xu, R. Lin, Q. Han, J. Li, R.C. Zhao (2012) MicroRNA-100 regulates osteogenic differentiation of human adipose-derived mesenchymal stem cells by targeting BMPR2. FEBS Lett 586 : 2375-2381.

Zhang, Y., N. Cheng, R. Miron, B. Shi, X. Cheng (2012) Delivery of PDGF-B and BMP-7 by mesoporous bioglass/silk fibrin scaffolds for the repair of osteoporotic defects. Biomaterials 33: 6698-6708.

Zhang, Y., L. Xia, D. Zhai, M. Shi, Y. Luo, C. Feng, B. Fang, J. Yin, J. Chang, C. Wu (2015) Mesoporous bioactive glass nanolayer-functionalized 3D-printed scaffolds for accelerating osteogenesis and angiogenesis. Nanoscale 7: 19207-19221.

Zhao, Q., H. Ren, Z. Han (2016) Mesenchymal stem cells: immunomodulatory capability and clinical potential in immune diseases. J Cell Immunother 2: 3-20.

Zomorodian, E., M. Baghaban Eslaminejad (2012) Mesenchymal stem cells as a potent cell source for bone regeneration. Stem Cells Int 2012: 9.

Zuk, P.A. (2008) Tissue engineering craniofacial defects with adult stem cells? Are we ready yet? Pediatr Res 63: 478-486.

Zuk, P.A., M. Zhu, P. Ashjian, D.A. De Ugarte, J.I. Huang, H. Mizuno, Z.C. Alfonso, J.K. Fraser, P. Benhaim, M.H. Hedrick (2002) Human adipose tissue is a source of multipotent stem cells. Mol Biol Cell 13: 4279-4295.

Zwingenberger, S., Z. Yao, A. Jacobi, C. Vater, R.D. Valladares, C. Li, C. Nich, A.J. Rao, J.E. Christman, J.K. Antonios, E. Gibon, A. Schambach, T. Maetzig, S.B. Goodman, M. Stiehler (2014) Enhancement of BMP-2 induced bone regeneration by SDF-1alpha mediated stem cell recruitment. Tissue Eng Part A 20: 810-818.
Role of MSCs in Bone Regenerative Medicine
Cells Tissues Organs 2017;204:59-83

DOI: $10.1159 / 000469704$ 